\title{
EVALUATING ACTIVE LABOR MARKET PROGRAMS IN ROMANIA
}

\author{
Nuria Rodriguez-Planas ${ }^{\dagger}$ \\ Universitat Autònoma de Barcelona \\ Jacob Benus \\ Impaq International \\ May 2006 \\ Last revised: May 2007
}

\begin{abstract}
We evaluate the presence of effects from joining one of four active labour market programs in Romania in the late 1990s compared to the no-program state. Using rich followup survey data and propensity score matching, we find that three programs (training and retraining, self-employment assistance, and employment and relocation services) had success in improving participants' economic outcomes and were cost-beneficial from society's perspective. In contrast, public employment was found detrimental for the employment prospects of its participants.
\end{abstract}

Key words: Active labour market programs, propensity score matching, transition economies, and net social benefits.

JEL classification: J24, J64, J68

${ }^{\dagger}$ Contacting author is Núria Rodríguez-Planas. Contact e-mail: Nuria.Rodriguez@uab.es

We are grateful to Lars Skipper for helpful comments and to participants of the EALE 2006 Conference in Prague, and the IAB 2005 conference on Labor Market Policy Evaluation in Nuremberg. Financial support from the Romanian Ministry of Labor and Social Protection, the National Agency for Employment and Vocational Training, the Spanish ministry of Education and Science (grant SEJ2006-712) and the Generalitat de Catalunya (grant SGR2005-712) is also gratefully acknowledged. Slavica Zec has provided excellent research assistance work. 


\section{Introduction}

Even though open unemployment was practically non-existent in Romania prior to 1989, with the introduction of social, political, and economic reforms, labour surplus soared. The restructuring process affected many workers who saw the value of their human capital deteriorate, and struggled into finding new job or business opportunities. The Romanian government soon recognized the urgency of developing social safety programs and active labour market programs (ALMPs hereafter) to help the unemployed during this transition period. Thus, in the early 1990s, the Ministry of Labor and Social Protection combined social insurance and means-tested income support with active policies aimed at increasing labor demand for youths, improving matching by providing retraining for unemployed individuals, and stimulating job creation through credits to businesses. However, the extent of these active programs remained limited, as discussed in Earle and Pauna, 1998. And it is not until the late 1990s that the Romanian government launched the real start of active programs on a significant scale by signing a loan agreement with the World Bank.

In this paper, we evaluate the effectiveness and efficiency of four active labor market programs that were implemented through this agreement in Romania at the end of the 1990s. These programs were: (1) training and retraining (TR), (2) self-employment assistance (SE), (3) public employment (PE), and (4) employment and relocation services (ER). The objective of the evaluation was to inform the Romanian Ministry of Labor and Social Protection and the National Agency for Employment and Vocational Training on the impacts of these programs on the employment experiences and earnings prospects of its participants as compared to the outcome if the individual had continued to search for a job as openly unemployed, that is, not participating in any of the ALMPs under evaluation. We also considered program costs and provide information as to whether the programs were cost-effective. The focus is on the direct effects of the programs; no attempt is made to assess the general equilibrium implications. ${ }^{1}$

Therefore, this study's contribution to the Romanian and the international literature is threefold. First, by providing an evaluation of the effects of four ALMPs implemented in Romania in the late 1990s, this paper increases our knowledge on what experiences work in transition economies. Second, we argue that our data is unusually rich for studies conducted in transition economies, which allows us to address the selection issues in a reasonable way. Third, we explore the net social benefits of those ALMPs found effective.

Our analysis is based on a follow-up survey specifically designed and collected for this evaluation. The most important reasons for using survey data instead of administrative data were that the former provided us with good quality data on key variables—such as earnings for both the employed and the self-employed, and allowed us to track individuals' earnings and employment status at different points in time over a four-year period. The data, a random sample of close to 4,000 persons who registered at the Employment Bureau during 1999, was collected during January and February 2002. Thus, we observe individuals at least 24 months

\footnotetext{
${ }^{1}$ For a theoretical macroeconomic framework for studying both the direct and indirect effects, see Layard, Nickell, and Jackman (1991), among others.
} 
after the programs started. About half of this sample (2,047 persons) were ALMP participants whose ALMP contract began in 1999. The other half did not participate in any of the four ALMPs under analysis.

We base our analysis on the conditional independence assumption (CIA), and use a kernelbased matching estimator to estimate the average treatment effect. A part of the paper is devoted to discussing the plausibility of the CIA in this context. One of the biggest challenges when evaluating ALMPs in transition economies is the quality and quantity of data-see Kluve, Lehmann and Schmidt, 1999, or Earle and Pauna, 1996, among others, for discussion on the poor quality of ALMPs' data in transition economies. We argue that our data contains important baseline information - in particular, pre-treatment earnings, employment history and experience information-making the CIA assumption more plausible.

Our analysis of program impacts reveals that three of the four programs (TR, SE and ER) had success in improving participants' economic outcomes and were cost-beneficial from society's perspective. We find that ER succeeded in increasing the likelihood of participants' employment and their earnings, and reducing the likelihood of receiving unemployment benefits. We also find that SE improved its participants' employment prospects, although it did not have a significant impact on their earnings; and that TR increased the earnings of its participants and reduced the likelihood of receiving unemployment benefits. In contrast, our analysis reveals that $\mathrm{PE}$ was found detrimental for the employment prospects of its participants.

While the literature on evaluations of ALMPs in developed market economies is vast, the evidence on transition countries is scarcer. ${ }^{2}$ Recently, several studies have studied the effectiveness of ALPMs in transition economies, like Bosnia and Herzegovina (Benus, Rude, and Patrabansh, 2001), Bulgaria (Walsh, Kotzeva, Dolle, and Dorenbos, 2001), Czech Republic (Boeri and Burda, 1996, Terrell and Sorm, 1999), Hungary (Gill and Dar, 1995, O’Leary 1995, O’Leary, 1998a, and O’Leary, Kolodziejczyk, and Lazar, 1998), Macedonia (World Bank, 2002), Poland (Kluve, Schmidt and Lehmann, 1999, Kluve Lehman and Schmidt, 2002, Puhani 1998, O’Leary, 1998b, and O’Leary, Kolodziejczyk, and Lazar, 1998), Slovak Republic (Lubyova and Van Ours, 1999), Slovenia (Vodopivec, 1999), and Ukraine (Kupets, 2000). Overall, our results are consistent with earlier findings, as discussed in our findings section, section VI. ${ }^{3}$

This paper is organized as follows. The next two sections present background information on Romanian labor market development, and the set up of the ALMPs under evaluation. Section four describes the data, sample selection and displays the descriptive statistics.

\footnotetext{
2 See Katz, 1994, Fay, 1996, Martin, 1998, Dar and Tzannatos, 1999, and Betcherman, Olivas, and Dar, 2004, for good reviews of the literature.

${ }^{3}$ Many rigorous evaluations have also studied the impact of ALMPs in East Germany, as illustrated by Eichler and Lechner, 2000, Fitzenberger, 2000, Kraus, Puhani, and Steiner, 1999, Lechner, 1998a, 1998b, 1999a, 1999b, 2000, and Hujer and Wellner, 2000, among others. Despite their interest, we limit our comparison of results to evaluations conducted in transition economies. We therefore do not discuss results from East Germany because of the extremely unique process this country experienced.
} 
Section five discusses the economic evaluation strategy and the empirical implementation. Section six displays the results. Section seven discusses heterogeneity among individuals and sensitivity analyses. Section eight concludes with the cost-benefit analysis.

\section{The Economic Context}

Romania's transition to a market economy has been slow and painful partly as a result of its stop-and-go approach to the restructuring process. Since the 1989 Revolution, successive governments have adopted a cautious approach to market-oriented reforms. This slow pace of reform-relative to some of its neighbours in Central Europe-delayed needed structural changes and added greater difficulties to the already unfavourable set of initial conditions inherited from the previous regime.

As shown in Figure 1, after an initial economic contraction in the early 1990s due to the increase of external competition and the abolition of the Council of Mutual Economic Assistance (CMEA), Romania experienced a partial economic recovery beginning in 1992, similar to the one observed in leading transition economies in Central Europe. However, in contrast with these leading economies, Romania lived a second period of economic decline beginning in 1996, which was mainly caused by the lack of enterprise restructuring. In the second half of 1996, Romania's authorities took a series of decisions with the aim of accelerating the privatization, restructuring and liquidation of unprofitable business. However, the recovery was slow and did not produced significant economic results until the year 2000. Since then the Romania economy has grown at an average of 4 or 5 per cent per year.

Figure 1

\section{Romania Economic Indicators, 1990-2001}

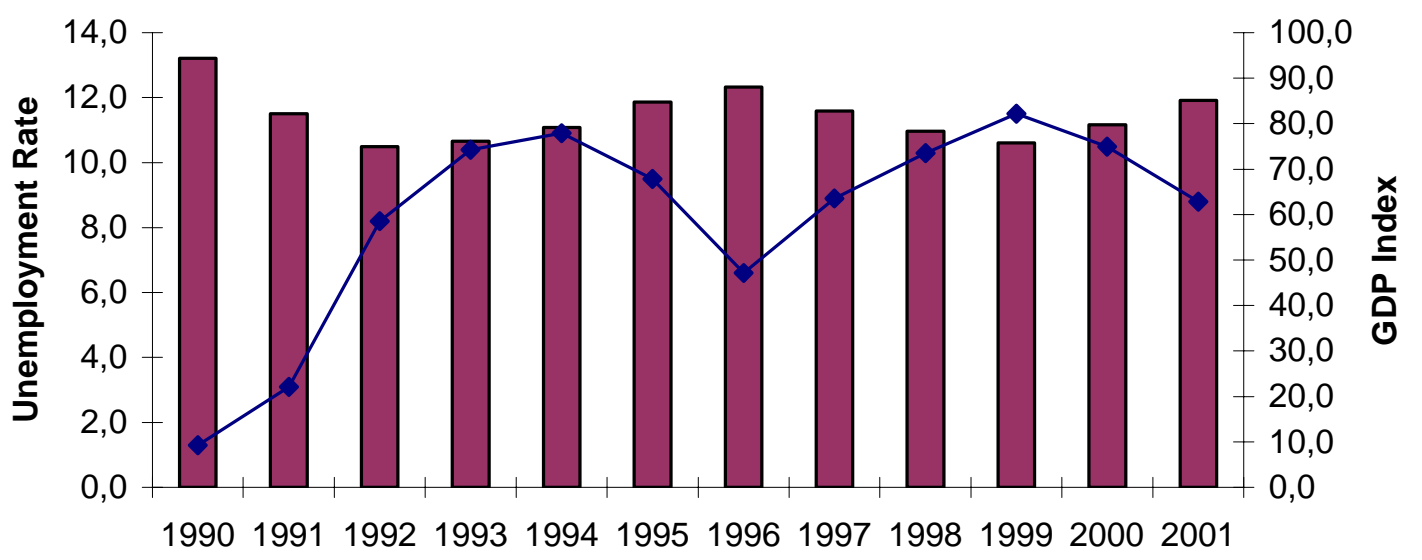

$\square$ GDP (1989 = 100) $\bullet-$ Unemployment Rate

The collapse in output at the beginning of the 1990s prompted an increase in unemployment. As shown in Figure 1, following the drop in output, registered unemployment soared and 
reached over 10 percent of the labor force in 1994. The unemployment rate then fell temporarily during 1995 and 1996, only to rise rapidly thereafter reaching 11.5 percent in 1999. Since then, the registered unemployment rate has fallen gradually to 9 percent of the labor force in 2001.

Data on registered unemployment in Romania understate the real problem with dislocated workers for at least the following three reasons. First, during the 1990s the increase in open unemployment was contained by Romania's policy approach of limiting job destruction by adjusting through real wages, combined with a series of early retirement programs. Even though these two policies succeeded in limiting the increase in registered unemployment, it pushed workers out of the labor force and into low productivity jobs, primarily in agriculture. Second, a high share of Romania's employment is in subsistence agriculture-the share of agricultural employment in Romania in 2001 was 42 percent of total employment (up from 28 percent of total employment in 1989). This suggests the existence of a two-tier system consisting of a large number of people involved in low productivity jobs and subsistence agriculture coexisting with large, potentially profitable but unreformed, farms. And third, the existence of borderline employment categories to measure employment in Romania substantially influences key indicators of labor market performance and suggest that many individuals in Romania are ready to work but that the limited opportunities prevent them from doing so. ${ }^{4}$

\section{Labour Market Programs}

Even though open unemployment was practically non-existent in Romania prior to 1989, with the introduction of social, political, and economic reforms, the emergence of labor surplus soared. The Romanian government soon recognized the urgency of developing programs to help the unemployed during this transition period. Thus, as early as 1991, the Ministry of Labor and Social Protection adopted the Romanian Unemployment Program. This program was not a pure social insurance program since it contained provisions for means-testing. ${ }^{5}$ According to this program, unemployed individuals were eligible for financial support through unemployment benefits, allowance for vocational integration, and support allowance. The conditions to be eligible were the following: to be registered at the local Labor Office, to be aged eighteen and over, to have an income less than half of the indexed national minimum wage, to be unemployed due to liquidation or a lay-off, and to have been employed at least six months during the last twelve months, or recent graduate from school or university unable to find suitable employment. Unemployment benefits were paid for a maximum duration of nine months. The level of these benefits ranged from 50 to 60 percent of the average monthly salary during the last three months of employment for laid-off workers. For new entrants, allowances for vocational integration

\footnotetext{
${ }^{4}$ Examples of borderline employment categories include unpaid family helpers, involuntary part-timers, or people in "technical" unemployment or unpaid leave initiated by the employer.

${ }^{5}$ It contained two means-testing elements: a ceiling on land ownership, and a ceiling on personal income of half the minimum wage. However, according to officials from the Ministry of Labor and from local offices the ceiling on land ownership was seldomly binding as the inefficiency and corruption of the process of land privatization lead to many new owners without titles, making it difficult to prove that the land was theirs, even though they may work it unofficially. In practice, the only consequences of the ceiling on personal income were a reduction in reported income.
} 
varied by the level of education and years of experience for those with prior work experience. After exhausting unemployment benefits, those who remained unemployed received a support allowance (of 60 percent of the indexed minimum wage) for a maximum period of 18 months. ${ }^{6}$

In the early 1990s, Romania also adopted several active policies aimed at increasing labor demand for youths, improving matching by providing retraining for many categories of unemployed individuals, and stimulating job creation through credits to businesses. ${ }^{7}$ However, the extent of these active programs remained limited, as discussed in Earle and Pauna, 1998. Thus, the need for additional and more diversified measures enabling to support employment emerged progressively and became particularly urgent after 1996-1997 when privatization and the restructuring accelerated and resulted in massive layoffs.

In the late 1990s, the Romanian government launched the real start of active programs on a significant scale by signing a loan agreement with the World Bank. The focus of the present paper is to evaluate the effectiveness of the four ALMPs implemented under this agreement: (1) training and retraining (TR), (2) small business assistance (SE), (3) public employment (PE), and (4) employment and relocation services (ER).

\section{Implementation of ALMPs}

Implementation of ALMPs began in 1997 by the National Agency for Employment and Vocational Training and the county agencies for Employment and Vocational Training. County level Agencies for Employment and Vocational Training designed and implemented Active Labor Measures for displaced workers. However, these services were not provided by the county agencies themselves, but were contracted out to public or private service providers. The county agencies were responsible for the public announcements of the tenders, conducting the tendering process, and contracting out the ALMPs.

Contracts to service providers were awarded with built-in incentives to improve labor market impact such as negotiated levels of job placement and business start-up, with financial incentives to meet objectives and disincentives if objectives were not met. Thus, service providers were likely to select those unemployed individuals most likely to succeed in completing their program and accessing employment. As we shall see in section IV, this will cause selection bias due to a correlation of individual program participation with the outcomes under investigation.

\section{Description of the Programmes}

\footnotetext{
${ }^{6}$ See Earle and Pauna (1998) for a detailed description and thourough analysis of the unemployment benefit and support allowance program in Romania.

${ }^{7}$ The first active measure to be adopted was training and retraining for the unemployed in 1991. Then in 1992, an important youth measure was initiated through the labor offices, the Wage Subsidy Program for New Graduates. In 1995, a program offering loans to small- and medium-sized enterprises that hired at least 50 percent of the new hires from the unemployment pool was also launched.
} 
The four programmes were clearly differentiated as evident from the description of their key characteristics presented in Table 1. While SE and ER offered services aiming to facilitate business start-ups for displaced entrepreneurs (the former), and job placement for recently unemployed workers (the latter), the other two programs were targeted to more difficult populations. TR offered vocational training, general education and literacy skills to those who lacked these basic skills or needed to learn new marketable ones. While PE was frequently considered as fully subsidised labour, and was mainly offered in those regions with the least economic opportunities.

The maximum length of these programs also varied, and ranged between six months—-for public service employment, and a year-for employment and relocation services. However, in practice, the length was considerably shorter than the established maximum duration. Participation in TR, PE, and ER increased the period in which individuals could receive benefits by the length of the program (in the case of TR and PE), and by a maximum of two months in the case of ER, adding an incentive for certain individuals to participate in the programs.

The requirements to service providers are key to understanding how the selection into the different programmes was done. In all programs, service providers had to agreed to a minimum negotiated job placement rate of an average of its participants. This rate was the lowest for SE programs, which had to agree to a negotiated business start-up rate of at least 5 percent of clients initially contacted, and highest for TR services, in which case local organizations proposing training programs had to show evidence of demand for trained workers and agree to a minimum negotiated job placement rate of an average of at least 60 percent. For the other two types of services, PW and ER, providers had to agree to negotiated job placement rates of at least 10 percent at the end of the program.

In addition, service providers had to demonstrate minimum capabilities to be service providers, such as staff qualifications, facilities, financial viability, and placement capability, and they had to agree certain provisions on eligible costs, and limits to reimbursement per service, as described in Table 2.

Finally, there were some requisites that prevented duplication of payment and services. First, individual clients could not receive income support payments (e.g., minimum wage during TR or PE) if they were receiving other types of state financed income support, such as unemployment benefits. Second, individuals could not participate in both TR and PE. And third, individuals were not allowed to participate more than once in a programme in a period of 24 months.

\section{Utilization of ALMPs}

As indicated in Table 3, among these four ALMPs, there were 767 contracts completed as of September 1, 2001, and over sixty-four thousand clients served. The overall placement rate among these contracts varied largely by program—ranging from $41 \%$ for TR to $13 \%$ for PE. 
The program with the largest number of clients (ER) provided assistance to 31,679 individuals at an average cost of only 123.74 thousand lei per client (about 12US\$ per client). In contrast, the PE served a much smaller number of clients $(9,496)$; the cost per client for this program was 2,915.77 thousand lei per client (about US\$294 per client). ${ }^{8}$

Based on discussions with program implementation staff, we determined that contracts that begun in 1999 most accurately reflect the operations of the ALMPs. Prior to 1999, the ALMPs were new and some of the procedures were not fully implemented. Contracts that begun after 1999 may not be suitable for the evaluation since some may still be in operation or recently finished at the time of the survey and impacts from these contracts may not yet be fully reflected in participants' outcomes. Thus, our sample was drawn from contracts that started during 1999.

\section{The Data and Descriptive Statistics}

\section{Data Source}

This study uses data from a follow-up survey of registered unemployed specifically designed for this evaluation. ${ }^{9}$ We shied away from using existing data from the Ministry of Labor and Social Protection for several reasons. First, we were concerned on the quantity and quality of the existing data. But, more importantly, data from the Ministry lacked several key variables needed for our analysis, such as earnings for both the employed and the selfemployed. ${ }^{10}$

Compared with existing data from the Ministry, our follow-up survey data provided much more detailed characteristics of the unemployed individuals, and observed their earnings and employment status at different points in time over a four-year period. Moreover, since official data is collected in the local labor offices, we were concerned that respondents would be more reluctant to fully disclose their earnings to public authorities (as part of tax avoidance strategy) than to trained interviewers from an outside independent agency. ${ }^{11}$

For these reasons, we contracted with a Romanian private survey firm, Institute of Marketing and Polls (IMAS), to conduct field surveys during January-February 2002. The study goal was to achieve over 4,000 respondents. Of the 5,735 individuals contacted for interviewing, about 70 percent responded. As is common in these type of studies, response rate was slightly higher for participants (72 percent) than for non-participants (68 percent).

\footnotetext{
${ }^{8}$ All costs figures have been deflated using 1998 deflator.

${ }^{9}$ Survey data of registered unemployed specifically collected for a study was used in Earle and Pauna, 1996 and Earle and Pauna, 1998.

${ }^{10}$ The Ministry of Labor and Social Protection provides some aggregate classifications on the unenmployed each month. These data, although useful, are limited to a few basic dimensions and allow few inferences concerning the origins, causes, and incidence of unemployment to be drawn.

${ }^{11}$ Previous studies have found evidence of this. For instance, O'Leary et al., 1998, found evidence that participants of self-employment assistance programs in Hungary could have been under-reporting earnings to interviewers who worked in local labor offices.
} 


\section{Sample Selection}

The data used in this study, a random sample of approximately 3,996 persons who registered at the Employment Bureau during 1999, was collected during January and February 2002. About half of this sample, 2,047 persons, were ALMP participants whose ALMP contract began in 1999. The other half did not participate in any of the four ALMPs under analysis.

To obtain a representative sample of ALMP participants, we randomly selected, for each of the four ALMPs, $10 \%$ of clients served in the fifteen counties with the largest number of clients served in 1999. ${ }^{12}$ These fifteen counties (judets) represented $86 \%$ of all clients served in 1999, and a broad spectrum of the Romanian economy with many sectors represented, including heavy industry, mining, and agriculture, among others. Moreover, these fifteen judets included some of the poorest judets in Romania (Botosoni and Vaslui -- north-east region) as well as some judets with substantial natural resources and highly developed industries (Cluj and Maramures -- north-west region).

The other half of the sample-the potential comparison group-were 1,949 persons who were registered at the Employment Bureau around the same time and in the same county than participants but who had not participated in an ALMP. To select non-participants, we first determined, for each of the four ALMPs, the number of participants that were selected for the participant sample in each of the judets. Next, in each county and for each ALMP, we randomly selected an equal number of non-participants from the same Employment Bureau register list.

The timing of events, shown in Figure 2, goes as follows. Some of the workers registered at the Employment Bureau during 1999 received services from one of the four ALMPs described above. The rest of the workers did not receive any of these services. Although it is possible that some of the program participants may have continued to receive services during the year 2000 (since the maximum duration of the ALMPs varied between 6 and 12 months), it is quite unlikely since, in practice, the length of these programs was considerably shorter. During January and February of 2002, we interviewed the selected sample of participants and non-participants. All interviewed persons were asked three types of questions: (1) questions on employment and earnings at the time of the survey, (2) retrospective questions on employment and earnings during the years 2000 and 2001, and (3) retrospective questions on employment and earnings during 1998, prior to participating in the ALMPs. Details regarding the outcome variables are given in Section VI.

Restriction that all data be available led to a sample of 3,396 individuals (1,627 participants and 1,501 non-participants). All the results presented below are robust to using

\footnotetext{
${ }^{12}$ Because of the low number of participants in the TR, we used a higher sampling rate (25\% of clients served) for this program.
} 
all of the observations available for each of the different outcome variables. However, in order to work with the same sample in the whole paper we restricted our sample to have all data available.

\section{Figure 2}

\section{TIMING OF EVENTS}

\begin{tabular}{|c|c|c|}
\hline During 1999 & \begin{tabular}{l|l}
2000 & 2001 \\
\end{tabular} & January/February 2002 \\
\hline $\begin{array}{l}\text { Displaced workers } \\
\text { registered at } \\
\text { Employment Bureau. } \\
\text { Some participated in } \\
\text { ALMP, some did not. }\end{array}$ & $\begin{array}{l}\text { Workers worked or looked for employment. } \\
\text { During 2000, some of the ALMP participants may } \\
\text { have continued to receive services. }\end{array}$ & Workers are interviewed \\
\hline
\end{tabular}

\section{Descriptive Statistics}

Tables 4 and 5 display descriptive statistics for socio-economic variables for the different subsamples that are defined by treatment status. The descriptive statistics conform to our expectations that different types of displaced workers participated in the different ALMPs. The results are summarized below.

Clearly, participants in PE are the most disadvantaged among the unemployed both in terms of level of education and employment history. They are the least educated, with one fifth of them having only primary school education. And they have the worse employment prospects since almost two thirds of them were not employed in 1998, and their average unemployment spell in 1998 was 9 months. Moreover, these participants are also the most likely to live in rural or small urban areas with high unemployment. This is in line with the idea that public employment is considered fully subsidised labor, and that it is offered mainly in those regions with the least economic opportunities.

On the other hand, participants in TR are the youngest among the four ALMPs with an average age of 39.1 years old and less than one fifth older than 45 years old. This is consistent with the idea that substantive human capital investments are more beneficial the longer the productive period of the recipients. However, the fact that participants in TR appear to have the highest predisposition for training with almost one fifth of this group participating in training in 1998, combined with their young age, low education level—almost 70 percent of them did not have a high-school degree in 1998, and poor employment perspective-as more than two fifths reported being unemployed in 1998, seems to suggest that this group consists of young workers with low education achievement and poor marketvalued skills who have difficulties entering the labor market. ${ }^{13}$

\footnotetext{
${ }^{13}$ Even though this group of participants have similar work experience than the other groups, we must remind the reader that a large number of people in Romania are involved in low productivity jobs, subsistence agriculture, and borderline employment that make their skills not necessarily valued in the profitable marketsee section II.
} 
In contrast, participants in SE and in ER have relatively more stable employment history during 1998 than participants of the other two ALMPs, as three fourths reported working during 1998. There are, however, clear differences between these two groups. While, participants in SE tend to be more educated with two fifths of them holding a highschool degree and one fifth of them holding a university degree, participants in ER are more likely to live in large urban areas.

Non-participants resemble the most to participants in ER and SE. However, they experienced considerably more stable and better paid employment during 1998. For example, two thirds of them were employed between 9 and 12 months in 1998. Moreover, with the exception of participants in public employment, which are predominantly males, nonparticipants have a higher share of men in their group.

\section{Identification and Estimation}

\section{The Evaluation Problem}

The evidence in the previous two sections shows that the ALMPs offered were considerably different and targeted to individuals with different skills and labour market experiences. Thus, we focus our analysis on comparing the outcomes of two alternative strategies available to displaced workers: to participate in a particular ALMP, or to continue searching for a job as openly unemployed, following the framework suggested by Rubin (1973). ${ }^{14}$

Let $\mathrm{Y}^{t}$ denote the outcome when a person gets the treatment (in this case, participates in one of the four ALMPs described above), and $\mathrm{Y}^{\mathrm{c}}$ denote the outcome when a person does not participate in any of the ALMPs described above. Let $\mathrm{D}$ denote a binary assignment indicator that determines whether the individual gets the treatment $(D=1)$ or not $(D=0)$.

The average treatment effect on the treated (ATET) is defined as follows:

$$
A T E T=E\left(Y^{t}-Y^{c} \mid D=1\right)=E\left(Y^{t} \mid D=1\right)-E\left(Y^{c} \mid D=1\right)
$$

The shorthand notation $\mathrm{E}(. \mid \mathrm{D}=1)$ denotes the mean in the population of all individuals who participate in an ALMP, denoted by $\mathrm{D}=1$.

ATET shows the expected effect of the program for those persons who actually participated. However, we cannot observe the counterfactual, $E\left(Y^{c} \mid D=1\right)$, i.e., the average outcome of those persons who participated in the program had they not participated. Thus, without further assumptions, ATETs are not identified. But if we can observe all factors that

\footnotetext{
${ }^{14}$ We considered basing our analysis on the "multiple treatments" model. However, the large socio-economic differences across the different treatments combined with the relative modest samples, lead to large losses of observations due to the common support requirement, and poor matching.
} 
jointly influence outcomes and participation decision, then-conditional on those factors (call them X), the participation decision and the outcomes are independent. This property is exploited by the conditional independence assumption (CIA).

\section{Is it Plausible to Assume Conditional Independence?}

Our approach for meeting the CIA was to include in the matching process: (1) characteristics influencing the decision to participate in ALMP, (2) baseline values of the outcomes of interest, (3) variables influencing the outcomes of interest, and (4) variables reflecting local labour market conditions, and regional differences in program implementation or local offices' placement policies.

The characteristics, implementation, and utilization of the different ALMPs as well as the characteristics of their participants indicates that the level of education, experience, previous earnings, and pre-program unemployment history are important factors in determining whether an individual will participate in any program, as well as in which of the programs. These factors are also likely to influence the future labour market outcomes, and thus, in order for CIA to be plausible, they should be included in the estimation of the propensities.

Demographic characteristics, such as age and gender are also important determinants of labour market prospects. Moreover, family composition and whether the person is the family's main wage earner are also likely to influence individual's decision to participate in a program.

We also include variables that capture the local labour market conditions. These variables measure the different employment opportunities in the judets. In addition, since differences in labour market conditions may favour a different mix of program and unemployment policies, these variables are also a proxy for different policy approaches across counties.

Finally, we include county dummies to capture unobserved local aspects that are likely to be correlated with program implementation and utilization, or local offices' placement policies, and thus relevant for program-joining decisions and individuals' potential labour market performance.

Although at first sight and relative to studies conducted in developped countries, these data may not seem suficiently rich to observe all relevant factors, we believe that our data is unusually rich for studies conducted in transition economies-see Kluve, Lehmann and Schmidt , 1999, or Earle and Pauna, 1996, among others, for discussion on the poor quality of ALMPs' data in transition economies. For instance, one could argue that, even though we control for employment and unemployment history during 1998, we lack of this type of information prior to 1998 (Heckman and Smith, 1999, point to the importance of controlling for employment dynamics prior to program participation.) Rich data on employment dynamics prior to program participation in studies on transition economies is unusual. Many of these studies do not have any employment information prior to participation (Lubyova and 
Van Ours, 1999, Puhani and Steiner, 1997, and Vodopivec, 1999, among others). Others have limited information on employment history prior to participation. For instance, while O'Leary et al., 1998, have information on prior employment status and whether the individual was a long-term unemployed, they do not control for months employed or unemployed prior to program participation. A study that has information on the length of unemployment spell that took place right before program participation is Terrel and Sorm's JCE 1999 paper. However, their information is limited to the year of participants' unemployment registration, which is, at most, the year prior to program entrance, and more often than not, the same year of program participation. Finally, to our knowledge, Kluve, Lehmann and Schmidt, 1999 and 2001, have the most thourough information on employment dynamics prior to participation in transition economies, and again, this information is limited to twelve months prior to entering the program.

Moreover, we have information on 1998 earnings, which can be considered a proxy for both workers' pre-displacement job characteristics and workers' motivation, ability and soft skills. Again, while baseline earnings data may be frequently available in developped countries, they are less common in transition economies' studies. The only study that we identified that controlled for baseline earnings data was Terrel and Sorm’s, $1999 .^{15}$

Finally, although we lack information on the willingness of the Employment Bureau staff of the different local offices to assign people into different programs, we control for several county characteristics that most likely capture most of these local differences. Again, while many evaluation studies in developped countries have information local labor offices' willingness to assign people into different programs, we were unable to find any study on ALMPs in transition economies that had this type of information.

Summarizing, the available data include much, but not all, information on factors, which affect the selection and the outcomes. The crucial question-that is left to the reader to decide - is whether there is sufficient information to justify the conditional independence assumption. However, we believe that our data frequently provides variables that contain some of this needed key information, and is at least qualitatively equal (if not superior) to data used in other evaluations of ALMPs in transition economies.

\section{Empirical Implementation}

We selected four comparison groups (one for each of the four groups of ALMPs participants) from the sample of potential comparison group members.

We used propensity scores to select comparison groups for each treatment group, according to the following three steps. First, we estimated a probit model separately for each

\footnotetext{
15 O’Leary et al., 1998, had information on net monthly household earnings, although it is unclear whether this information was used to control for selection bias.
} 
ALMP. We included the following variables in the probit models: male; age indicators; education indicators; earnings in 1998; 1998 experience (and its square); unemployed at least nine months in 1998; length of unemployment during 1998 (and its square); only employed during 1998; received training during 1998; 1998 judet unemployment rate; region's size; and regional indicators. Table 6 displays the estimation results of the four different binary probits and provides a more exact description of the variables used in the analysis.

Second, we used the output from these selection models to estimate choice probabilities conditional on $\mathrm{X}$ (the so-called propensity scores) for each treatment and potential comparison group member. We then imposed the common-support requirement to guarantee that there is an overlap between the propensity scores for each pair (see column 9 of Table 7 for number of treated observations lost due to this requirement).

Third, for each treatment group member, we selected potential comparison group members based on their propensity scores and their judet. The selection process was done with replacement, so that a potential comparison group member could have been matched to more than one treatment group member. ${ }^{16}$ In addition, the selection method used was kernelbased matching, which uses all of the comparison units within a predefined propensity score radius (or "caliper of 1\%"). When there were multiple matches, each non-participant received a weight that reflects the number of successful matches within the caliper range. ${ }^{17}$

\section{Similarity of the Treatment and Comparison Groups}

Our goal was to select, for each of the four groups, a well-matched comparison group. A comparison group is well matched to a treatment if the estimated propensity score and the collection of available baseline characteristics are not significantly different across the two groups.

The results in Table 7 show statistical information on the quality of the match for each of the four ALMPs. Columns 4 and 5 give an indication of how well baseline covariates explain the participants' probability before (column 4) and after (column 5) the match. Not surprisingly, after the match the $\mathrm{R}^{2}$ decreases considerably. Similarly, the P-value of the likelihood ratio test after matching shows that the null hypothesis of joint significance of regressors is always rejected after the matching (column 6). The median bias after the matching is also considerably reduced (columns 7 and 8).

Overall, results in Table 7 show that matching on the estimated propensity score balances the X's in the matched samples extremely well (and better than the other versions of

\footnotetext{
${ }^{16}$ Matching with replacement minimizes the propensity-score distance between the matched comparison units and the treatment unit: each treatment unit can be matched to the nearest comparison unit, even if a comparison unit is matched more than once. This is beneficial in terms of bias reduction, but may reduce the precision of the estimates. An additional advantage of matching with replacement instead of without replacement is that the results are not sensitive to the order in which the treatment units are matched (Rosenbaum, 1995).

${ }^{17}$ By using more comparison units, one increases the precision of the estimates, but at the cost of increased bias.
} 
matching we experimented with). To adjust for the additional sources of variability introduced by the estimation of the propensity score as well as by the matching process itself, bootstrapped confidence intervals have been calculated.

\section{Program Impacts}

\section{Measurement of Labour Market Outcomes}

Because the primary objective of these policies is to get displaced workers back to work in jobs, at least implicitly, as good as the previous one, our analysis focuses in two types of outcomes: those that measure workers' reemployment probabilities and those that measure workers' earnings at the new job. Moreover, since our survey included retrospective questions, we measure these outcomes at two different points in time: at the time of the survey, and during the two-year period prior to the survey, that is, during the years 2000 and 2001.

In addition to measuring employment experience with employment and average usual monthly earnings at the time of the survey, we compute two variables that measure the reemployment probability for a period of at least 6 and 12 months, respectively, during the years 2000 and 2001. These two variables provide additional information on workers' reemployment experiences over the two-year period prior to the survey, and inform us on the workers' employment attachment over that period. We also include average usual monthly earnings during the two-year period prior to the survey as a proxy for worker's productivity. ${ }^{18}$ Finally, we include duration of the unemployment spell and months receiving unemployment benefits (UB) during the two-year period 2000-2001. Table 8 describes the outcomes of interest and Table 9 summarizes these outcomes by treatment status.

\section{Mean Effects of the Programmes for their Participants}

Impacts were estimated as the difference in average outcomes between the treatment and the comparison group, and are shown in Table 10. They are summarized below.

\section{Employment and Relocation Services.}

First, we find that ER was successful in improving participants' economic outcomes compared to non-participants in all dimensions. ER had a positive impact both on current employment and on employment during the years 2000-2001. For instance, it increase the probability of being employed at the time of the survey by 8.45 percentage points, which represents a $20 \%$ increase in the likelihood of being employed at the time of the survey. ${ }^{19}$ Partly as a result of its positive impacts on employment, the program reduced the number of

\footnotetext{
18 All earnings variables are deflated by gross domestic product (base=1998), and coded as zero if person reported not working at the time of the survey.

${ }_{19}$ This result is calculated by dividing the ATET estimate (in this case, 8.45) by the percent of matched nonparticipants employed at the time of the survey, which is 42.83 percent.
} 
months unemployed and receiving UB during the 2000-2001. Finally, ER had a positive impact on earnings: it increased average current monthly earnings by 57 thousand lei (or $22 \%$ ) and average monthly earnings during 2000-2001 by 87 thousand lei (or 28\%) compared to the earnings of non-participants.

We identified four studies that evaluated job search assistance and related employment services in transition economies. These studies took place in the Czeck Republic (Terrell and Sorm, 1999), Macedonia (World Bank, 2002), Hungary and Poland (O’Leary, 1998a). Similar to our findings, all of these studies found positive impacts of ER type of services on improving employment prospects of participants. However, of the two evaluations that estimated the impact of these services on earnings, only in Poland a positive effect was found. $^{20}$

\section{Self-Employment Assistance}

We also find that SE improved its participants' employment prospects. More specifically, SE increased by 8.38 percentage points (or 12\%) the likelihood of being employed for 6 months during the two-year period 2000-2001. This programme also reduced the number of months participants were on average unemployed compared to non-participants by almost two months, and the number of months receiving UB payments by almost one month. However, we did not find that SE increased the average monthly earnings of its participants relative to non-participants. This lack of result could be explained by entrepreneurs under-reporting their earnings.

We identified three studies that evaluated self-employment assistance programs in the following transition countries: Bulgaria (Walsh, Kotzeva, Dolle, and Dorenbos, 2001), Hungary and Poland (O’Leary, 1998a). Consistent with our results, the three programs increased the probability of reemployment. However, the evidence on earnings is mixed. While our study found no effect on earnings, the study from Hungary found a negative effect, while the study from Poland found a positive one. The Bulgarian program did not estimate the impact of the program on earnings.

\section{Training and Retraining}

We find that TR has a positive and large impact on the average usual monthly earnings perceived during 2000-2001: it increased the earnings of participants by 165 thousand lei relative to the earnings of non-participants. This is equivalent to $58 \%$ higher earnings than non-participants. TR also had an impact on the length of UB receipt, by making it practically non-existent on average among its participants (see Table 9). Unfortunately, due to the small sample size of our sample of TR participants, we lack precision for the other estimates. However, the size of these estimates is consistent with TR being successful in improving participants' economic outcomes compared to non-participants.

We identified ten different studies that have evaluated training programs aimed at the unemployed in transition economies. Such TR programs have taken place in Bosnia and

\footnotetext{
${ }^{20}$ The evaluation conducted in Hungary in the mid-1990s found no impact on earnings.
} 
Herzegovina (Benus, Rude, and Patrabansh, 2001), Bulgaria (Walsh, Kotzeva, Dolle, and Dorenbos, 2001), Hungary (Gill and Dar, 1995, and O’Leary 1995a), Macedonia (World Bank, 2002), Poland (Kluve, Schmidt and Lehmann, 1999, Kluve Lehman and Schmidt, 2002, Puhani 1998, O’Leary, 1998b), and Slovak Republic (Lubyova and Van Ours, 1999). These evaluations consistently find that training programs for unemployed workers improve participants' employment prospects in the short-term. These results are in line with our findings, which point to positive (although insignificant) estimates on employment prospects, and positive and significant impact on earnings and on unemployment insurance receipt.

\section{Public Employment Programs}

In contrast, we find that the PE program had a negative impact on employment, and length of unemployment spell during the past two years. These detrimental effects are usually explained by one or a combination of the following two explanations. First, participating in PE may be ineffective insofar as it does not rebuild human capital, boost search efforts or improve the image of the long-term unemployed individual. Second, participation in PE is a negative signal to the employer (Lehmann, 1995).

We identified the following eleven studies that evaluated public employment programs in transition economies: Bulgaria (Walsh, Kotzeva, Dolle, and Dorenbos, 2001), Hungary (O’Leary, 1995, and O’Leary, 1998(a)) Macedonia (World Bank, 2002b), Poland (Kluve, Schmidt and Lehmann, 1999, Kluve Lehman and Schmidt, 2002, Puhani 1998, O’Leary, 1998b), Slovak Republic (Lubyova and Van Ours, 1999), Slovenia (Vodopivec, 1999), and Ukraine (Olga, 2000). Overall, the results were mixed. While two evaluations in Poland concluded, as in our study, that PE had a significant negative effect on exiting unemployment and future employment. Evaluations in Macedonia, Slovakia, Slovenia, and Ukraine found that a positive employment effect disappeared if the worker did not find a job immediately after the program ended, suggesting that employers may be using $\mathrm{PE}$ as a screening device before committing to formal employment. Finally, a small positive impact on employment was found in Bulgaria. However, this positive result was small compared to other ALMPs, and was achieved at a high unit cost.

\section{Heterogeneity and Sensitivity Analysis}

In this section we explore the robustness of the results presented above. We first examine the sensitivity of the results to various estimators. Second, we examine heterogeneity among various types of individuals.

\section{Sensitivity of the results to various estimators}

One way to check the robustness of the results, is to apply various estimators to the same problem to see whether the results differ. We compared the results obtained by matching to some alternative estimators. Tables 11 through 14 present impact estimates for the effect of the ALMPs on various employment outcomes and earnings in Romania using four alternative estimators. The first set of results (first column of Tables 11 through 14) is gross impact estimates, which were not adjusted for observable differences between the participant 
and non-participants, that is, we use our whole sample of non-participants regardless of whether their baseline characteristics resembled to those of participants. The second set of results (second column of Tables 11 through 14) is net impact estimates, which were adjusted for demographic and regional differences, and earnings, employment, unemployment and training experiences in 1998 using multivariate ordinary least squares regression (when the dependent variable was continuous) or probit regression (when the dependent variable was a binary variable). The covariates included in the OLS and the probit estimations are the same as those used to estimates the propensity scores in Table 10 and column 4 of Table 11 . The third set of results are net impact estimates that were computed as simple differences between the mean outcome of interest for the participant group and the mean outcome for a nonexperimentally matched comparison group selected by the same propensity score method described in section $\mathrm{V}$, however, we did not use any of the pre-earnings, pre-employment, and pre-unemployment history to match participants to non-participants. The fourth set of results are the estimators presented in section VI and Table 10.

The most obvious overall result in Table 10 through 14 is that the unadjusted impact estimates (column 1) are generally different from the other estimates (columns 2 through 4). For TR, SB and ER, the unadjusted impact estimates were better than the other ones, suggesting that operators may "cream off" the most qualified candidates among the unemployed for these particular types of programs. This finding is consistent with other analyses of ALMP in transition economies (O’Leary,1998 and Kluve, Lehmann, and Schmidt, 2001, among others). In contrast, adjusting for observable characteristics reduces the detrimental employment and unemployment impact estimates on PE (Table 13). In particular, the sensitivity of the results to the availability of different covariates-not shown here, but available from the author upon request-indicates that information on the regional location of participants and non-participants was essential when measuring this program's impacts, suggesting that programs like public employment may be used as a regional policy by "bringing work to the workers", that is, creating job in high unemployment regions.

Comparing the gross impact estimates with the regression-adjusted estimates (column 1 versus column 2) clearly reduces the positive impact of SE estimates and the negative impact of PE estimates, reflecting that there is an over-representation of individuals with "better" observable characteristics in the group of SE participants and an over-representation of individuals with "worse" observable characteristics in the group of PE participants. In the case of TR, we find that regression-adjusting the estimates reduces the positive effect of TR on current employment and earning outcomes, and increases it on employment and earnings outcomes over the last two years. Finally, regression-adjusting the estimates has little effect on ER findings, leaving most estimates unchanged. The two exceptions are average monthly earning perceived over the two year period 2000-2001 and months unemployed, for which adjusting for observables raises the positive effect.

Comparing columns 2 and 4 provides us with a comparison between results obtained by matching with the standard OLS regression for the continuous dependent variables, and a probit model for the discrete dependent variables. As in the matching approach, identification of the average treatment effects in these models requires conditional independence. 
Moreover, the estimators are based on further parametric restrictions.

We observe substantial differences between the OLS and probit estimators on the one hand, and matching on the other for the cases of TR, ER, and PE. For TR and ER, we find that the results obtained by matching reduce the positive employment effects of TR and SE. Whereas for PE we find that the matching estimates reflect a smaller negative impact on employment outcomes for participants-the negative impact disappears in the case of outcomes measuring current employment and earnings. These differences are presumably explained by the parametric restrictions underlying the OLS and probit estimations. Matching allows for heterogeneity in the treatment effect in a more flexible way.

Comparing estimates from column 3 and 4 enable us to explore the importance of controlling for pre-earnings, pre-employment, and pre-unemployment history. We find that these variables are very essential when measuring the effect of the different programs, as reflected by the fact that excluding them raises the size of impact estimates of all programs.

\section{Heterogeneity among Types of Individuals}

So far we have considered the average effects for the participants in the different programmes. Since participants are heterogeneous, there may be differences in how the programmes affect different types of individuals. Therefore, we stratify the sample along the dimensions unemployment duration, type of region, age, education, and gender, and match within strata. Below, we summarize the key findings (all subgroup estimates are displayed in Tables 15 through 18).

Clearly, the most substantial (and significant) differences occur with respect to age, type of region, and unemployment duration prior to participation for the ER programme. These differences are displayed in Table 18. We find that ER improves economic outcomes of participating for younger workers, workers with histories of short-term unemployment, and those living in rural areas compared to older workers, those with histories of long-term unemployment, and those living in urban areas, respectively.

We also find relevant subgroup differences across individuals participating in SE. In particular, we find that SE is more successful for females than for males, for workers without a high-school diploma than for those with, and for workers living in rural areas compared to those in urban areas.

Even though we find that PE seems to have a positive effect on the employment probability and the earnings of participants living in rural areas at the time of the survey, this result does not hold when employment and earnings outcomes are measured during the period 2000-2001. Thus, this positive effect of PE in rural areas is most likely explained by participants re-entering $\mathrm{PE}$ once the requisite that "participants do not participate in more than one ALMP during a 24 months period" is satisfied.

Although, we did not find any statistically significant different impacts of training and 
retraining for different subgroups, this is likely due to the lack of precision due to small subsample sizes.

\section{Cost-Benefit Analysis and Conclusion}

The purpose of this study has been to analyse the effects of four ALMPs implemented in Romania during the late 1990s. Our analysis is based on data from a follow-up survey especially designed for this study. We use nonparametric matching estimators to control for potential selection bias. Our analysis of program impacts reveals that three of the four programs (TR, SE and ER) had success in improving participants' economic outcomes. In contrast, our analysis reveals that PE was found detrimental for the employment prospects of its participants.

Even though this analysis has shown significant positive impacts of TR, SE, and ER programmes implemented in Romania in the late 1990s, the question remains as to whether these three ALMPs were cost-effective from society's perspective. ${ }^{21}$ While there is some scattered data on costs, the cost-benefit issue has rarely been addressed. ${ }^{22}$ Hence we now compare the costs per client of the ALMP with the economic benefits, as reflected in predicted earnings.

We estimate the average cost per client served by dividing the total amount spent in each ALMP by the number of clients served. Table 2 displays these estimates. The cost per client served is 541.07 thousand lei for TR, 179.15 thousand lei for SE, and 123.74 thousand lei for ER.

To estimate the benefits of the policy, we use the estimated impact of these ALMPs on the usual average monthly earnings of their participants. We prefer using the earnings estimates over the 2000-2001 period because they are more likely to represent individuals' earnings than those observed at one point in time. This amounts to an annual sum of 5,393.04 thousand lei for TR, 4,783.20 thousand lei for SE (although this estimate was not statistically significant), and 1,047.84 thousand lei for ER, which cover by far the cost per client served. Therefore, these three policies are definitively cost-effective. ${ }^{23}$

A caveat in our cost-benefit analysis is that we did not include among potential benefits: (1) possible effects on labour market behaviour of the unemployed prior to participation, such as, intensifying job search before entering the programmes in order to avoid participation, or leaving the labour force and stop collecting UB; (2) reduced criminal

\footnotetext{
${ }^{21}$ When measuring cost-effectiveness from society's perspective, we measure whether aggregate benefits from implementing the policy are greater than the aggregate resources spent by the policy, abstracting from who enjoys its benefits and who bears its costs. Thus, under this perspective, increases in taxes paid due to the increased employment of participants or reductions in public assistance of participants are not counted as they are transfers from participants to the rest of society.

${ }^{22}$ This is particularly true for studies in transition economies.

${ }^{23}$ Given that benefits that accrue within the observation period are above the costs, we did not use a long-term perspective to estimate cost-effectiveness.
} 
activity due to improved employment prospects; (3) improvements in the quality of life for participants and their families, (4) savings in the deadweight losses due to reduced taxes required to pay participants' future unemployment benefits. Another caveat is that we did not considered in this analysis the following potentially important costs: (1) the deadweight loss of taxation to finance benefits, subsidies, and operation of programmes; (2) the cost of the leisure forgone while participants are in the program or employed; and (3) possible displacement effects of non-subsidized workers. However, given that the measured benefits far exceed the costs of the programmes, we are confident that, at least the SE and ER, programs were socially beneficial undertakings for the unemployed in our sample. 


\section{REFERENCES}

Bechterman, G., K. Olivar, and A. Dar. "Impact of Active Labor Market Programs: New Evidence from Evaluations with Particular Attention to Developing and Transition Countries”. 2004. Social Protection Discussion Paper Series, No. 0402.

Benus J., J. Rude, and S. Patrabansh. "Impact of the Emergency Demobilization and Reintegration Project in Bosnia \& Herzegovina,” Abt Associates, April 2001.

Boeri D., and Burda. “Active Labor Market Programs, Job Matching, and the Czech Miracle,” 1996. European Economic Review, 805-817.

Dar A., and Z. Tzannatos. "Active Labor Market Programs: A Review of the Evidence from Evaluations,” 1999. Social Protection Discussion Paper no. 9901. The World Bank, Washington, D.C.

Earle, J. and C. Pauna. "Incidence and Duration of Unemployment in Romania," 1996. European Economic Review 49: 829-837.

Earle, J. and C. Pauna. "Long-term Unemployment, Social Assistance and Labour Market Policies in Romania,” 1998. Empirical Economics, 23:203-235.

Eichler, M. and M.Lechner. "Some Econometric Evidence on the Effectiveness of Active Labor Market Programmes in East Germany,” 2000. Working Paper no. 318. Swiss Institute for International Economics and Applied Economic Research (SIW). Switzerland.

Fay, R.G. "Enhancing the Effectiveness of Active Labor Market Policies: Evidence from Programme Evaluations in OECD countries," 1996. Labor Market and Social Policy Occasional Papers, No. 18, Paris.

Fitzenberger, B., and H.Prey. "Evaluating Public Sector Sponsored Training in East Germany,” 2000. Oxford Economic Papers 52, no.3: 497-520.

Gill I., and A. Dar. "Cost and Effectiveness of Retraining in Hungary,” 1995. Internal Discussion Paper IP-155, Europe and Central Asia Region, The World Bank.

Heckman, J., and J. Smith. "The Preprogram Earnings Dip and the Determinants of Participation in a Social Program: Implications for Simple Program Evaluation Strategies,” 1999. Economic Journal, 108: 313-348.

Hujer, R. and M. Wellner. "The Effects of Public Sponsored Training on Individual Employment Performance in East Germany,” 2000. Working Paper, Frankfurt: J.W. Goethe University. 
Katz L. “Active Labor Market Policies to Expand Employment and Opportunity,” 1994. Proceedings, Federal Reserve Bank of Kansas City, issue January, p. 239-322.

Kluve, J., H. Lehmann, C. Schmidt, “Active Labor Market Policies in Poland: Human Capital Enhancement, Stigmatisation, or Benefit Churning?,” 1999. Journal of Comparative Economics, Vol 27.

Kluve, J., H. Lehmann, C. Schmidt, "Disentanglin Treatment Effects of Polish Active Labour Market Policies: Evidence from Matched Samples,” 2002. Discussion Paper no. 3298, April London, UK: Center for Economic Policy Research.

Kraus, F., P. Puhani and V. Steiner. "Employmnet Effects of Publicly Financed Training Programs-The East Germany Experience,” 1999. Jahrbucher fur Nationalokonomie und Statistik 219, no. 1-2:216-48.

Kupets, O.. “The Impact of Active Labor Market Policies on the Outflows from Unemployment to Regular Jobs in Ukraine,” 2000. Thesis for the degree of Master of Arts in Economics. Nation University. Kiev Mohyla Academy.

Layard, R., S. Nickell, and R. Jackman. Unemployment, Macroeconomic Performance and the Labor Market. 1991. Oxford: Oxford University Press.

Lehmann Harmut, "Active Labor Market Policies in the OECD and in Selected Transition Economies,” 1995 Policy Research Working Paper 1502, World Bank.

Lechner M. "Continuous Off-the-Job Training in East Germany after Unification: Preliminary Results of an Evaluation of the Short-Run Effects for Individual Workers," 1998a. In Horst Brezinski, Egon Franck and Michael Fritsch (Eds.), The microeconomics of transformation and growth (pp. 205-30). Cheltenham, U.K. and Northampton, Mass.: Elgar; distributed by American International Distribution Corporation Williston VT.

Lechner M. "Training the East German Labour Force: Microeconometric Evaluations of Continuous Vocational Training After Unification,” 1998b. Studies in Contemporary Economics. Heidelberg: Physica.

Lechner M. "Earnings and Employment Effects of Continuous Off-the-Job Training in East Germany After Unification,” 1999a. Journal of Business and Economic Statistics 17, no. 1:74-90.

Lechner M. "The Effects of Enterprise-Related Training in East Germany on Individual Employment and Earnings," 1999b. Annales d'Economie et de Statistique 0, no. 55-56: 97128.

Lechner, M. “An Evaluation of Public-Sector-Sponsored Continuous Vocational Training Programs in East Germany,” 2000 Journal of Human Resources 35, no. 2:347-75. 
Lubyova, M., van Ours, J.C. "Effects of Active Labor Market Programs on the Transition Rate from Unemployment into Regular Jobs in the Slovak Republic”, 1999. Journal of Comparative Economics 27, no. 466:805-37.

Martin, J.P., "What Works among Active Labor Market Policies: Evidence form OECD Countries’ Experiences”, 1998. Labor Market and Social Policy Occasional Papers No. 35. Paris.

O’Leary, C. “An Impact Analysis of Employment Programs in Hungary,” 1995. Upjohn Institute Technical Report No 95-30.

O’Leary, C. J. “Evaluating the Effectiveness of Active Labor Programs in Hungary,” 1998a. Upjohn Institute Technical Report No 98-013.

O’Leary, C. J. "Evaluating the Effectiveness of Active Labor Programs in Poland,” 1998b. Upjohn Institute Technical Report No 98-012.

O’Leary, C. J., P. Kolodziejczyk, and G. Lazar. “The Net Impact of Active Labour Programmes in Hungary and Poland,” 1998. International Labour Review, 137(3), 321-346.

Puhani, P. "Advantage through Training? A Microeconometric Evaluation of the Employment Effects of Active Labour Market Programmes in Poland," 1998. ZEW Discussion Paper no. 98-25, Manheim.

Puhani P. and V. Steiner. "The Effectiveness and Efficiency of ALMP in Poland," 1997. Empirica 24, p. 209-231.

Rosenbaum P., and Rubin, D. "The Central Role of the Propensity Score in Observational Studies for Causal Effects,” 1983. Biometrika 27, no.1:33-60.

Rubin, Donald B. "Matching to Remove Bias in Observational Studies." Biometrics, vol. 29, 1973, pp. 159-183.

Terrell, K., and V. Sorm. "Labor Market Policies and Unemployment in the Czech Republic,” 1999. Journal of Comparative Economics 27, no. 1:33-60.

Vodopivec, M. "Does the Slovenian Public Work Program Increase Participants' Chances to Find a Job?,”1999. Journal of Comparative Economics 27, no. 1:113-30.

Walsh, K; M. Kotzeva, E. Dolle, and R. Dorenbos. "Evaluation of the Net Impact of Active Labour Market Programs in Bulgaria”, 2001. Ministry of Labour and Social Policy, Bulgaria.

World Bank. "Evaluation of Active Labor Programs in Macedonia. Final Report,” 2002.

Social Reform and Technical Assistance Project. IDA-2722-MK. 
Table 1

Characteristics of ALMPs

\begin{tabular}{|c|c|c|c|c|}
\hline & $\begin{array}{c}\text { Training and } \\
\text { Retraining }\end{array}$ & $\begin{array}{c}\text { Self-Employment } \\
\text { Assistance }\end{array}$ & Public Employment & $\begin{array}{c}\text { Employment and } \\
\text { Relocation Services }\end{array}$ \\
\hline $\begin{array}{l}\text { Content of the } \\
\text { program }\end{array}$ & $\begin{array}{l}\text { Vocational, general } \\
\text { education and } \\
\text { literacy, and formal } \\
\text { business skills } \\
\text { training }\end{array}$ & $\begin{array}{l}\text { Initial assessment of } \\
\text { the aptitude and skills } \\
\text { of unemployed } \\
\text { persons to start } \\
\text { businesses, } \\
\text { developing business } \\
\text { plans, advising on } \\
\text { accounting, financial, } \\
\text { legal, marketing and } \\
\text { sales services issues, } \\
\text { assistance in the } \\
\text { dialogue with local } \\
\text { authorities, short-term } \\
\text { entrepreneurial } \\
\text { courses and training } \\
\text { and other consulting } \\
\text { services }\end{array}$ & $\begin{array}{l}\text { Environmental } \\
\text { cleanup, ecological } \\
\text { projects related to } \\
\text { infrastructure, } \\
\text { refurbishment of } \\
\text { public infrastructure, } \\
\text { and provision of } \\
\text { assistance and support } \\
\text { to social agencies, } \\
\text { such as schools, or } \\
\text { retirement homes }\end{array}$ & $\begin{array}{l}\text { Job and social } \\
\text { counseling, labor } \\
\text { market information, } \\
\text { job search assistance, } \\
\text { job placement } \\
\text { services, and } \\
\text { relocation assistance }\end{array}$ \\
\hline $\begin{array}{l}\text { Maximum } \\
\text { duration }^{\mathrm{a}}\end{array}$ & Up to nine months & $\begin{array}{l}\text { No general rule, up to } \\
12 \text { months }\end{array}$ & Up to six months & Up to nine months \\
\hline $\begin{array}{l}\text { Participants' } \\
\text { stipend }\end{array}$ & $\begin{array}{l}\text { Subsistence stipend } \\
\text { was at the minimum } \\
\text { wage level and for a } \\
\text { period equal to the } \\
\text { difference between } \\
\text { the months of } \\
\text { unemployment } \\
\text { benefits and months } \\
\text { of training }\end{array}$ & $\begin{array}{l}\text { There were provisions } \\
\text { for short-term } \\
\text { working capital loans } \\
\text { of up to } \$ 25,000 \text { U.S. } \\
\text { dollars to program } \\
\text { participants }\end{array}$ & $\begin{array}{l}\text { Stipend was set at a } \\
\text { maximum of the } \\
\text { average wage level of } \\
\text { the type of activity } \\
\text { provided and for the } \\
\text { duration of the } \\
\text { program }\end{array}$ & $\begin{array}{l}\text { Up to two months of } \\
\text { salary at the } \\
\text { minimum wage. } \\
\text { In addition, those } \\
\text { clients receiving } \\
\text { relocation assistance } \\
\text { could be reimbursed } \\
\text { for expenses } \\
\text { associated with } \\
\text { moving to another } \\
\text { community-up to } \\
\$ 500 \text { U.S. dollars } \\
\text { equivalent in lei per } \\
\text { family, based on } \\
\text { submission of } \\
\text { receipts. }\end{array}$ \\
\hline Target group & $\begin{array}{l}\text { Persons exposed to } \\
\text { high risk of } \\
\text { unemployment }\end{array}$ & $\begin{array}{l}\text { Unemployed } \\
\text { entrepreneurs who } \\
\text { intended to start, or } \\
\text { who had started } \\
\text { businesses during the } \\
\text { past } 12 \text { months }\end{array}$ & $\begin{array}{l}\text { Long-term } \\
\text { unemployed }\end{array}$ & Recently unemployed \\
\hline $\begin{array}{l}\text { Negotiated } \\
\text { placement rate } \\
\text { of at least: }\end{array}$ & 60 percent & 5 percent & 10 percent & 10 percent \\
\hline
\end{tabular}

${ }^{\mathrm{a}}$ In practice, the length of these programs was considerably shorter than the established maximum duration. Source: USDOL Technical Assistance Support Team. 
Table 2

Eligible Costs and Limits of Reimbursement for Service Providers

\begin{tabular}{|c|c|c|c|c|}
\hline & $\begin{array}{l}\text { Training and } \\
\text { Retraining }\end{array}$ & $\begin{array}{c}\text { Self-Employment } \\
\text { Assistance }\end{array}$ & Public Employment & $\begin{array}{c}\text { Employment and } \\
\text { Relocation Services }\end{array}$ \\
\hline Eligible costs & $\begin{array}{l}\text { Eligible costs } \\
\text { included cost of } \\
\text { training and } \\
\text { administrative } \\
\text { personnel, rent and } \\
\text { utilities, consumable } \\
\text { materials, client } \\
\text { transportation, non- } \\
\text { durable goods, } \\
\text { capital depreciation } \\
\text { up to } 20 \text { percent per } \\
\text { year. }\end{array}$ & $\begin{array}{l}\text { Eligible costs included } \\
\text { personnel services, } \\
\text { transportation costs, } \\
\text { rent and utilities, } \\
\text { consumable materials } \\
\text { and non-durable } \\
\text { goods, and capital } \\
\text { depreciation up to } 20 \\
\text { percent per year. }\end{array}$ & $\begin{array}{l}\text { These public works } \\
\text { projects covered the } \\
\text { cost of supervisory } \\
\text { personnel and up to } 6 \\
\text { months of program } \\
\text { participants' } \\
\text { stipends. Other } \\
\text { eligible costs } \\
\text { included } \\
\text { transportation costs, } \\
\text { related training costs, } \\
\text { utilities, and } \\
\text { consumable and non- } \\
\text { durable goods. }\end{array}$ & $\begin{array}{l}\text { Eligible costs } \\
\text { included staff and } \\
\text { administrative } \\
\text { personnel costs, rent } \\
\text { and utilities, } \\
\text { consumable } \\
\text { materials, client } \\
\text { transportation for job } \\
\text { interviews, non- } \\
\text { durable goods, and } \\
\text { depreciation of } \\
\text { capital equipment up } \\
\text { to } 20 \text { percent per } \\
\text { year. }\end{array}$ \\
\hline $\begin{array}{l}\text { Limits of } \\
\text { reimbursement }\end{array}$ & $\begin{array}{l}\text { The cost of training } \\
\text { was limited to } \$ 560 \\
\text { U.S. dollars per class } \\
\text { unit. }\end{array}$ & $\begin{array}{l}\text { Costs per client had to } \\
\text { be specified in all } \\
\text { contracts, however } \\
\text { unit costs could be } \\
\text { identified for different } \\
\text { categories of services } \\
\text { by each service } \\
\text { provider based on the } \\
\text { understanding that all } \\
\text { clients did not need } \\
\text { full services and some } \\
\text { may drop out after } \\
\text { initial contacts. } \\
\text { Reimbursement to } \\
\text { service providers was } \\
\text { based on the } \\
\text { contracted average } \\
\text { cost per client, for } \\
\text { each category } \\
\text { services. }\end{array}$ & $\begin{array}{l}\text { Proposing } \\
\text { organizations had to } \\
\text { provide evidence of } \\
\text { administrative and } \\
\text { financial viability. } \\
\text { Local governments } \\
\text { and other eligible } \\
\text { organizations could } \\
\text { propose public works } \\
\text { projects with a } \\
\text { maximum cost of } \\
\text { \$50,000 U.S. dollars } \\
\text { (or higher with a no- } \\
\text { objection from the } \\
\text { World Bank). }\end{array}$ & \\
\hline
\end{tabular}

Source: USDOL Technical Assistance Support Team. 


\section{Table 3}

Completed ALMP contracts as of September 1, 2001

\begin{tabular}{lccccccc}
\hline & $\begin{array}{c}\text { Number } \\
\text { of } \\
\text { contracts }\end{array}$ & $\begin{array}{c}\text { Clients } \\
\text { served }\end{array}$ & $\begin{array}{c}\text { Clients } \\
\text { placed }\end{array}$ & $\begin{array}{c}\text { Placement } \\
\text { rate }\end{array}$ & $\begin{array}{c}\text { Total cost } \\
\text { (Lei) }\end{array}$ & $\begin{array}{c}\text { Cost per } \\
\text { client } \\
\text { (Lei) }\end{array}$ & $\begin{array}{c}\text { Cost per } \\
\text { placement } \\
\text { (Lei) }\end{array}$ \\
\hline $\begin{array}{l}\text { Training and } \\
\text { retraining }\end{array}$ & 54 & $2,892.00$ & 1,197 & $41.39 \%$ & $1.564,771,985.06$ & $541,069.15$ & $1,307,244.77$ \\
$\begin{array}{l}\text { Self- } \\
\begin{array}{l}\text { Employment } \\
\text { Assistance }\end{array}\end{array}$ & 92 & $20,293.00$ & 3,568 & $17.58 \%$ & $3,635,562,636.30$ & $179,153.53$ & $1,018,935.72$ \\
$\begin{array}{l}\text { Public } \\
\text { employment }\end{array}$ & 533 & $9,496.00$ & 1,248 & $13.14 \%$ & $27,688,156,974.32$ & $2,915,770.53$ & $22,186,023.22$ \\
$\begin{array}{l}\text { Employment } \\
\text { and }\end{array}$ & & & & & & & \\
$\begin{array}{l}\text { relocation } \\
\text { services }\end{array}$ & 88 & $31,679.00$ & 6,610 & $20.87 \%$ & $3,920,060,312.43$ & $123,743.18$ & $593,049.97$ \\
\hline
\end{tabular}

Costs figures have been deflated using 1998 deflator.

Source: USDOL Technical Assistance Support Team. 
Table 4

Baseline Demographic and Regional Characteristics of

ALMP Participants and Non-Participants, 1998

(Percentages except where noted)

\begin{tabular}{|c|c|c|c|c|c|}
\hline & $\begin{array}{c}\text { Training and } \\
\text { Retraining } \\
\text { (1) }\end{array}$ & $\begin{array}{c}\text { Self- } \\
\text { Employment } \\
\text { Assistance } \\
(2) \\
\end{array}$ & $\begin{array}{c}\text { Public } \\
\text { Employment } \\
\text { (3) } \\
\end{array}$ & $\begin{array}{c}\text { Employment } \\
\text { and } \\
\text { Relocation } \\
\text { Services } \\
\text { (4) } \\
\end{array}$ & $\begin{array}{c}\text { Non- } \\
\text { participants } \\
(5) \\
\end{array}$ \\
\hline \multicolumn{6}{|l|}{ Characteristics } \\
\hline \multicolumn{6}{|c|}{ Personal characteristics } \\
\hline Male & 45.83 & 50.69 & 89.89 & 45.92 & 63.82 \\
\hline \multicolumn{6}{|l|}{ Age } \\
\hline Less than 31 years old & 5.56 & 4.99 & 13.03 & 7.50 & 8.93 \\
\hline Between 31 and 35 years old & 27.78 & 22.71 & 19.33 & 14.59 & 16.46 \\
\hline Between 36 and 45 years old & 47.22 & 40.44 & 38.43 & 40.16 & 36.58 \\
\hline Between 45 and 50 years old & 15.28 & 17.73 & 18.20 & 20.62 & 19.79 \\
\hline More than 50 years old & 4.17 & 14.13 & 11.01 & 17.14 & 18.25 \\
\hline \multicolumn{6}{|l|}{ Education completed } \\
\hline Primary school & 5.56 & 9.97 & 21.12 & 13.25 & 14.86 \\
\hline Secondary school & 63.89 & 32.41 & 56.85 & 45.92 & 44.30 \\
\hline High school & 27.78 & 37.67 & 18.65 & 28.65 & 29.31 \\
\hline University & 2.78 & 19.45 & 3.71 & 12.82 & 11.26 \\
\hline \multicolumn{6}{|c|}{ Family characteristics } \\
\hline Family size & $\begin{array}{l}3.68 \\
(0.1)\end{array}$ & $\begin{array}{c}3.59 \\
(0.62)\end{array}$ & $\begin{array}{c}4.06 \\
(0.07)\end{array}$ & $\begin{array}{c}3.64 \\
(0.05)\end{array}$ & $\begin{array}{c}3.65 \\
(0.03)\end{array}$ \\
\hline Main family earner & 38.89 & 42.38 & 55.06 & 44.31 & 46.04 \\
\hline \multicolumn{6}{|c|}{ Regional information } \\
\hline \multicolumn{6}{|l|}{ Region } \\
\hline Rural & 8.33 & 5.82 & 35.06 & 11.24 & 17.92 \\
\hline $\begin{array}{l}\text { Urban with less than } 20 \\
\text { thousand inhabitants }\end{array}$ & 18.06 & 35.46 & 19.10 & 18.34 & 18.45 \\
\hline $\begin{array}{l}\text { Urban with } 20 \text { - } 79 \text { thousand } \\
\text { inhabitants }\end{array}$ & 16.67 & 14.13 & 39.10 & 20.08 & 28.11 \\
\hline $\begin{array}{l}\text { Urban with } 80 \text { - } 199 \text { thousand } \\
\text { inhabitants }\end{array}$ & 27.78 & 27.15 & 5.39 & 39.89 & 25.98 \\
\hline $\begin{array}{l}\text { Urban with } 200 \text { thousand } \\
\text { inhabitants }\end{array}$ & 29.17 & 17.45 & 1.35 & 10.44 & 9.53 \\
\hline Judet's unemployment rate & 10.67 & 11.37 & 15.76 & 11.86 & 13.12 \\
\hline Sample size & 72 & 362 & 445 & 747 & 1,501 \\
\hline
\end{tabular}

Standard deviation in parenthesis for continuous variables. 
Table 5

Baseline Employment Characteristics of

ALMP Participants and Non-Participants, 1998

(Percentages except where noted)

\begin{tabular}{|c|c|c|c|c|c|}
\hline & $\begin{array}{l}\text { Training and } \\
\text { Retraining } \\
\text { (1) }\end{array}$ & $\begin{array}{l}\text { Self- } \\
\text { Employment } \\
\text { Assistance } \\
\text { (2) }\end{array}$ & $\begin{array}{c}\text { Public } \\
\text { Employment } \\
\text { (3) }\end{array}$ & $\begin{array}{c}\text { Employment } \\
\text { and } \\
\text { Relocation } \\
\text { Services } \\
\text { (4) }\end{array}$ & $\begin{array}{l}\text { Non- } \\
\text { participants } \\
\text { (5) }\end{array}$ \\
\hline \multicolumn{6}{|l|}{ Characteristics } \\
\hline \multicolumn{6}{|c|}{ Work Experience } \\
\hline Work experience (years) & $\begin{array}{l}21.43 \\
(0.83)\end{array}$ & $\begin{array}{l}22.99 \\
(0.42)\end{array}$ & $\begin{array}{l}21.74 \\
(0.39)\end{array}$ & $\begin{array}{l}23.99 \\
(0.30)\end{array}$ & $\begin{array}{l}23.63 \\
(0.23)\end{array}$ \\
\hline \multicolumn{6}{|c|}{1998 Employment status } \\
\hline Not employed in 1998 & 45.83 & 23.82 & 59.10 & 22.36 & 19.19 \\
\hline Employed in 1998 & 54.17 & 76.18 & 40.90 & 77.64 & 80.81 \\
\hline $\begin{array}{l}\text { Employed between } 1 \text { and } 3 \\
\text { months in } 1998\end{array}$ & 4.17 & 1.39 & 5.62 & 4.42 & 2.53 \\
\hline $\begin{array}{l}\text { Employed between } 4 \text { and } 6 \\
\text { months in } 1998\end{array}$ & 12.5 & 6.37 & 16.85 & 8.70 & 7.40 \\
\hline $\begin{array}{l}\text { Employed between } 7 \text { and } 9 \\
\text { months in } 1998\end{array}$ & 4.17 & 3.05 & 8.09 & 10.71 & 5.53 \\
\hline $\begin{array}{l}\text { Employed between } 9 \text { and } 12 \\
\text { months in } 1998\end{array}$ & 33.33 & 65.37 & 10.34 & 53.82 & 65.36 \\
\hline Not employed in 1998 & 45.83 & 23.82 & 59.10 & 22.36 & 19.19 \\
\hline \multicolumn{6}{|c|}{1998 usual monthly earnings } \\
\hline \multicolumn{6}{|l|}{ Earnings per month } \\
\hline Under 500 thousand lei & 1.39 & 4.43 & 4.94 & 5.22 & 3.00 \\
\hline 500 - 600 thousand lei & 9.72 & 3.05 & 2.02 & 5.22 & 4.46 \\
\hline 601 - 700 thousand lei & 2.78 & 5.82 & 5.82 & 9.64 & 7.13 \\
\hline 701 - 850 thousand lei & 6.94 & 13.02 & 6.74 & 14.19 & 12.26 \\
\hline 851 - 1,000 thousand lei & 12.5 & 10.80 & 5.39 & 15.66 & 14.72 \\
\hline 1,001 - 1,200 thousand lei & 9.72 & 13.30 & 12.58 & 13.79 & 14.06 \\
\hline $1,201-1,500$ thousand lei & 6.94 & 13.30 & 3.60 & 7.36 & 10.79 \\
\hline 1,501 - 1,900 thousand lei & 2.78 & 5.54 & 1.13 & 3.88 & 6.79 \\
\hline $1,901-2,500$ thousand lei & 1.39 & 4.16 & 0.45 & 1.20 & 5.40 \\
\hline More than 2,500 thousand lei & 0 & 2.77 & 0.45 & 1.47 & 2.20 \\
\hline Average monthly earnings & 522.92 & 881.72 & 384.16 & 758.07 & 926.60 \\
\hline (in thousand lei) & $(65.25)$ & (39.38) & $(25.64)$ & $(22.51)$ & $(17.88)$ \\
\hline \multicolumn{6}{|c|}{ Unemployment experience in 1998} \\
\hline \multirow{2}{*}{$\begin{array}{l}\text { Average unemployment length } \\
\text { during } 1998 \text { (months) } \\
\text { Unemployed at least } 9 \text { months } \\
\text { during } 1998\end{array}$} & $\begin{array}{l}6.26 \\
(0.58)\end{array}$ & $\begin{array}{l}3.38 \\
(0.25)\end{array}$ & $\begin{array}{c}8.75 \\
(0.19)\end{array}$ & $\begin{array}{c}3.90 \\
(017)\end{array}$ & $\begin{array}{c}2.99 \\
(0.11)\end{array}$ \\
\hline & 45.83 & 23.27 & 60.67 & 23.56 & 18.85 \\
\hline \multicolumn{6}{|c|}{ Training experience in 1998} \\
\hline Received training during 1998 & 18.06 & 8.86 & 4.04 & 6.69 & 3.13 \\
\hline Average training length during & 0.68 & 0.29 & 0.15 & 0.26 & 0.10 \\
\hline 1998 (months) & $(0.19)$ & $(0.06)$ & $(0.04)$ & $(0.05)$ & $(0.02)$ \\
\hline Sample size & 72 & 362 & 445 & 747 & 1,501 \\
\hline
\end{tabular}

Standard deviation in parenthesis for continuous variables. 
Table 6

Results from the binomial probit estimations

\begin{tabular}{|c|c|c|c|c|}
\hline & $\begin{array}{l}\text { Training and } \\
\text { retraining } \\
\text { (1) }\end{array}$ & $\begin{array}{c}\text { Self- } \\
\text { Employment } \\
\text { Assistance } \\
\text { (2) }\end{array}$ & $\begin{array}{c}\text { Public } \\
\text { employment } \\
\text { (3) }\end{array}$ & $\begin{array}{c}\text { Employment } \\
\text { and relocation } \\
\text { (4) }\end{array}$ \\
\hline \multicolumn{5}{|l|}{ Characteristics } \\
\hline \multirow[t]{2}{*}{ Male } & .1713 & -.2015284 & .4609385 & -.1427264 \\
\hline & $(.1948181)$ & $(.0926006)$ & $(.1283769)$ & $(.0725004)$ \\
\hline \multirow[t]{2}{*}{ Age } & .3892 & .0284343 & .0961576 & .0140676 \\
\hline & (.3195778) & (.1061328) & $(.1062873)$ & $(.0929445)$ \\
\hline \multirow[t]{2}{*}{ Age squared } & -.0047 & -.0004043 & -.0010315 & -.0001519 \\
\hline & (.0038289) & $(.0012505)$ & $(.0012378)$ & (.0010719) \\
\hline \multicolumn{5}{|l|}{ Education completed } \\
\hline \multirow[t]{2}{*}{ Secondary school } & .6765 & .0398253 & -.1328247 & .0801002 \\
\hline & $(.3441943)$ & $(.1420994)$ & $(.1140381)$ & (.1099728) \\
\hline \multirow[t]{2}{*}{ High school } & .2033 & .3389603 & -.2036724 & -.0840283 \\
\hline & $(.3623174)$ & $(.1468737)$ & $(.1386652)$ & $(.1175862)$ \\
\hline \multirow[t]{2}{*}{ University } & -.0648 & .6136505 & -.3965541 & -.0083351 \\
\hline & $(.490365)$ & $(.1687934)$ & $(.2151126)$ & $(.1411292)$ \\
\hline \multicolumn{5}{|l|}{ Persons in the household } \\
\hline \multirow[t]{2}{*}{ Three } & .0475 & .1021722 & -.0426679 & .0232715 \\
\hline & $(.2794365)$ & (.1271709) & $(.1395565)$ & $(.1042423)$ \\
\hline \multirow[t]{2}{*}{ Four } & -.1809 & .0459635 & .1387877 & .133011 \\
\hline & $(.279879)$ & $(.1259283)$ & $(.1311306)$ & $(.1018456)$ \\
\hline \multirow[t]{2}{*}{$>$ four } & -.1987 & .0726954 & .164182 & .0280627 \\
\hline & $(.3207308)$ & $(.1431552)$ & $(.1377938)$ & $(.1143186)$ \\
\hline \multirow[t]{2}{*}{ Respondent is the main earner } & -.0642 & -.1547861 & -.0809511 & .0962171 \\
\hline & $(.2694773)$ & $(.1348952)$ & $(.1153289)$ & $(.1111627)$ \\
\hline \multirow[t]{2}{*}{ Respondent is spouse of main earner } & -.0171 & -.3095629 & -.2172834 & -.0487241 \\
\hline & $(.2698388)$ & $(.1379943)$ & $(.1344928)$ & $(.1115485)$ \\
\hline \multicolumn{5}{|l|}{ Region } \\
\hline \multirow[t]{2}{*}{ Urban $<20$ thousand inhabitants } & -.1565 & .4965981 & .3770499 & -.1270346 \\
\hline & $(.4181727)$ & $(.1689958)$ & $(.1320217)$ & $(.1306713)$ \\
\hline \multirow[t]{2}{*}{ Urban (20-79 thousand inhabitants) } & .7201 & .2525536 & .20623 & .2316202 \\
\hline & $(.4157758)$ & $(.1768784)$ & $(.1191083)$ & $(.124284)$ \\
\hline \multirow{2}{*}{$\begin{array}{l}\text { Urban ( } 80-199 \text { thousand } \\
\text { inhabitants) }\end{array}$} & .1096 & .0461624 & -.0415508 & .3309776 \\
\hline & $(.3873757)$ & $(.1719474)$ & $(.1780473)$ & $(.119047)$ \\
\hline \multirow[t]{2}{*}{ Urban (200 thousand inhabitants) } & .9841 & .7366886 & -.9707113 & -.0189794 \\
\hline & (.5197499) & $(.2738287)$ & $(.3477729)$ & $(.1976237)$ \\
\hline \multirow[t]{2}{*}{ Counties' unemployment rate } & -.5158 & -.1610341 & .0404204 & .0894544 \\
\hline & $(.2246201)$ & $(.0342555)$ & $(.0459796)$ & $(.0627584)$ \\
\hline \multirow[t]{2}{*}{ Work experience (years) } & -.1100 & .0356114 & -.0053237 & .0307314 \\
\hline & $(.1621206)$ & $(.0539121)$ & $(.0564912)$ & $(.0490692)$ \\
\hline \multirow[t]{2}{*}{ Experience squared } & .0021 & -.0007137 & -.000234 & -.0007828 \\
\hline & $(.0033456)$ & $(.001081)$ & $(.0011154)$ & $(.0009607)$ \\
\hline
\end{tabular}


Table 6 (Continued)

Results from the binomial probit estimations

\begin{tabular}{|c|c|c|c|c|}
\hline & $\begin{array}{l}\text { Training and } \\
\text { retraining } \\
\text { (1) }\end{array}$ & $\begin{array}{c}\text { Self- } \\
\text { Employment } \\
\text { Assistance } \\
\text { (2) }\end{array}$ & $\begin{array}{c}\text { Public } \\
\text { employment } \\
\text { (3) }\end{array}$ & $\begin{array}{c}\text { Employment } \\
\text { and relocation } \\
\text { (4) }\end{array}$ \\
\hline \multicolumn{5}{|l|}{ Characteristics } \\
\hline \multicolumn{5}{|l|}{1998 employment spell } \\
\hline 1-3 months & $\begin{array}{c}-1.3069 \\
(.9093462)\end{array}$ & $\begin{array}{c}-.9830641 \\
(.499512)\end{array}$ & $\begin{array}{c}.1871584 \\
(.3420969)\end{array}$ & $\begin{array}{c}-.6807008 \\
(.3418347)\end{array}$ \\
\hline 4-6 months & $\begin{array}{c}.5223 \\
(.8894968)\end{array}$ & $\begin{array}{l}-.1562037 \\
(.4336655)\end{array}$ & $\begin{array}{l}.0601928 \\
(.3414572)\end{array}$ & $\begin{array}{l}-.6466339 \\
(.3363872)\end{array}$ \\
\hline 7-9 months & $\begin{array}{c}-.0938 \\
(.8874751)\end{array}$ & $\begin{array}{l}-.2502013 \\
(.4274598)\end{array}$ & $\begin{array}{l}.2297862 \\
(.3266278)\end{array}$ & $\begin{array}{l}-.3247323 \\
(.3236533)\end{array}$ \\
\hline 9-12 month & $\begin{array}{c}.6000 \\
(.9295796)\end{array}$ & $\begin{array}{l}.9910766 \\
(.4134734)\end{array}$ & $\begin{array}{l}-.1674585 \\
(.3296845)\end{array}$ & $\begin{array}{l}-.123323 \\
(.2971646)\end{array}$ \\
\hline $\begin{array}{l}\text { Average earnings per month in } 1998 \\
\text { (in thousand lei) (wage } 98 \text { ) }\end{array}$ & $\begin{array}{c}-.0016 \\
(.0004077)\end{array}$ & $\begin{array}{c}-.0000 \\
(.0000943)\end{array}$ & $\begin{array}{c}-.0003 \\
(.0001549)\end{array}$ & $\begin{array}{c}-.0001 \\
(.0000854)\end{array}$ \\
\hline $500-600$ & $\begin{array}{c}1.2480 \\
(.5832753)\end{array}$ & $\begin{array}{c}-.2457 \\
(.2942938)\end{array}$ & $\begin{array}{c}-.6796 \\
(.3086426)\end{array}$ & $\begin{array}{c}-.1813 \\
(.2095827)\end{array}$ \\
\hline $601-700$ & $\begin{array}{c}.6409 \\
(.6014568)\end{array}$ & $\begin{array}{c}-.1330 \\
(.249114)\end{array}$ & $\begin{array}{c}-.3222 \\
(.2664017)\end{array}$ & $\begin{array}{c}-.2447 \\
(.1841415)\end{array}$ \\
\hline 701-850 & $\begin{array}{c}.7412 \\
(.518917)\end{array}$ & $\begin{array}{c}-.0327 \\
(.2145763)\end{array}$ & $\begin{array}{c}-.2518 \\
(.2322484)\end{array}$ & $\begin{array}{c}-.1748 \\
(.1698717)\end{array}$ \\
\hline $851-1,000$ & $\begin{array}{c}1.1921 \\
(.4613879)\end{array}$ & $\begin{array}{c}-.2962 \\
(.2074279)\end{array}$ & $\begin{array}{c}-.1687 \\
(.2431542)\end{array}$ & $\begin{array}{c}-.2043 \\
(.1625509)\end{array}$ \\
\hline $1,001-1,200$ & $\begin{array}{c}1.0384 \\
(.4632318)\end{array}$ & $\begin{array}{c}-.3793 \\
(.1984934)\end{array}$ & $\begin{array}{c}.4523 \\
(.2317394)\end{array}$ & $\begin{array}{c}-.1763 \\
(.1622569)\end{array}$ \\
\hline $1,201-1,500$ & $\begin{array}{c}1.5699 \\
(.4753651)\end{array}$ & $\begin{array}{c}-.1055 \\
(.1972956)\end{array}$ & $\begin{array}{c}-.2128 \\
(.2754237)\end{array}$ & $\begin{array}{c}-.3851 \\
(.1724099)\end{array}$ \\
\hline $1,501-1,900$ & $\begin{array}{c}1.7622 \\
(.5583888)\end{array}$ & $\begin{array}{c}-.3607 \\
(.2262893)\end{array}$ & $\begin{array}{c}-.1731 \\
(.3575139)\end{array}$ & $\begin{array}{c}-.4094 \\
(.1938586)\end{array}$ \\
\hline $1,901-2,500$ & n.a. & $\begin{array}{c}-.3758 \\
(.2408035)\end{array}$ & $\begin{array}{c}-.8899 \\
(.498729)\end{array}$ & $\begin{array}{c}-.9456 \\
(.2595758)\end{array}$ \\
\hline $\begin{array}{l}1998 \text { average unemployment spell } \\
\text { (months) }\end{array}$ & $\begin{array}{c}.6457 \\
(.1682585)\end{array}$ & $\begin{array}{c}.3975 \\
(.0973285)\end{array}$ & $\begin{array}{c}.2787 \\
(.0788757)\end{array}$ & $\begin{array}{c}.5042 \\
(.0673983)\end{array}$ \\
\hline Avg. unemployment spell squared & $\begin{array}{c}-.0646 \\
(.014862)\end{array}$ & $\begin{array}{c}-.0289 \\
(.009252)\end{array}$ & $\begin{array}{c}-.0181 \\
(.0070304)\end{array}$ & $\begin{array}{c}-.0387 \\
(.0071279)\end{array}$ \\
\hline 1998 unemployed at least 9 months & $\begin{array}{c}2.9805 \\
(1.099017)\end{array}$ & $\begin{array}{c}.6637 \\
(.7353178)\end{array}$ & $\begin{array}{c}.0427 \\
(.5103883)\end{array}$ & $\begin{array}{c}.2608 \\
(.5406227)\end{array}$ \\
\hline Received training during 1998 & $\begin{array}{c}-.0509 \\
(1.085547)\end{array}$ & $\begin{array}{c}.5994 \\
(.5026792)\end{array}$ & $\begin{array}{c}-.5666 \\
(.5482321)\end{array}$ & $\begin{array}{l}-.2614 \\
(.42072)\end{array}$ \\
\hline 1998 average training length (months) & $\begin{array}{c}.5509 \\
(.5871206) \\
\end{array}$ & $\begin{array}{c}-.0084 \\
(.2404551) \\
\end{array}$ & $\begin{array}{c}.2683 \\
(.2746366) \\
\end{array}$ & $\begin{array}{c}.1144 \\
(.1907319)\end{array}$ \\
\hline Sample size & 768 & 1,326 & 1,829 & 1,775 \\
\hline
\end{tabular}

All regressions include county dummies. Pseudo $R^{2}$ for all four specifications are presented in Table 7. 
Table 7

Indicators on the quality of the match, by ALMP

\begin{tabular}{|c|c|c|c|c|c|c|c|c|c|}
\hline ALMP & $\begin{array}{c}\text { Number of } \\
\text { treated } \\
\text { before } \\
\text { (1) }\end{array}$ & $\begin{array}{c}\text { Number of } \\
\text { nontreated } \\
\text { before } \\
\text { (2) }\end{array}$ & $\begin{array}{l}\text { Treated as a } \\
\text { percentage } \\
\text { of } \\
\text { nontreated } \\
\text { before } \\
\text { (3) }\end{array}$ & $\begin{array}{c}\text { Probit } \\
\text { pseudo- } R^{2} \\
\text { before } \\
\text { (4) }\end{array}$ & $\begin{array}{c}\text { Probit } \\
\text { pseudo- } \boldsymbol{R}^{2} \\
\text { after } \\
\text { (5) }\end{array}$ & $\begin{array}{c}\text { Pr }>X^{2} \\
\text { After } \\
\text { (6) }\end{array}$ & $\begin{array}{c}\text { Median } \\
\text { bias before } \\
\text { (7) }\end{array}$ & $\begin{array}{c}\text { Median } \\
\text { bias after } \\
\text { (8) }\end{array}$ & $\begin{array}{c}\text { Number of } \\
\text { treated lost } \\
\text { to common } \\
\text { support } \\
\text { after } \\
\text { (9) }\end{array}$ \\
\hline $\begin{array}{l}\text { Training and } \\
\text { retraining }\end{array}$ & 72 & 696 & 10.34 & 0.368 & 0.035 & 0.850 & 27.24 & 5.69 & 11 \\
\hline $\begin{array}{l}\text { Self-Employment } \\
\text { Assistance }\end{array}$ & 362 & 964 & 37.55 & 0.162 & 0.013 & 0.985 & 11.31 & 2.29 & 12 \\
\hline $\begin{array}{l}\text { Public service } \\
\text { employment }\end{array}$ & 445 & 1,384 & 32.15 & 0.359 & 0.013 & 0.996 & 24.64 & 1.87 & 6 \\
\hline $\begin{array}{l}\text { Employment and } \\
\text { relocation services }\end{array}$ & 747 & 1,028 & 72.67 & 0.174 & 0.017 & 0.533 & 9.36 & 2.88 & 4 \\
\hline
\end{tabular}

(1) Number of treated, that is, joining an ALMP program in 1999.

(2) Number of potential comparisons, that is, persons who had registered at the Employment Bureau in 1999 but did not participate in an ALMP.

(3) Treated as a percentage of potential comparisons.

(4) Pseudo- $R^{2}$ from probit estimation of the joining probability on $X$, giving an indication of how well the regressors $X$ explain the participants probability.

(5), (6), (7), and (10) are postmatching indicators on kernel-based matching (1\% caliper).

(5) Pseudo- $R^{2}$ from probit estimation of the joining probability on $X$ on the matched samples.

(6) P-value of the likelihood ratio test after matching. After matching, the joint significance of the regressors is always rejected. Before matching, , the joint

significance of the regressors was never rejected at any significance level, with $\operatorname{Pr}>X^{2}=0.0000$.

(7), and (8) Median absolute standardized bias before and after matching, median taken over all regressors $X$. Following Rosembaum and Rubin (1985), for a given covariate $X$, the standardized difference before matching is the difference of the sample means in the full treated and nontreated subsamples as a percentage of the square root of the average of the sample variances in the full treated and nontreated groups. The standardized difference after matching is the difference of the sample means in the matched treated, that is, the common support, and matched nontreated subsamples as a percentage of the square root of the average of the sample variances in the full nontreated groups:

$B_{\text {before }}(X) \equiv 100 \cdot \frac{\bar{X}_{1}-\bar{X}_{0}}{\sqrt{\left[V_{1}(X)+V_{0}(X)\right] / 2}}$ and $B_{\text {after }}(X) \equiv 100 \cdot \frac{\bar{X}_{1 M}-\bar{X}_{0 M}}{\sqrt{\left[V_{1}(X)+V_{0}(X)\right] / 2}}$

Note that the standardization allows comparisons between variables $X$ and, for a given $X$, comparisons before and after matching.

(9) Number of treated individuals falling outside of the common support (based on a caliper of $1 \%$ ). 
Table 8

\section{Description of outcome variables}

\begin{tabular}{|c|c|}
\hline Variables & Definition \\
\hline \multicolumn{2}{|l|}{ At the time of the survey } \\
\hline Employed & Person was employed at the time of the survey (dummy variable) \\
\hline Average monthly earnings & Average monthly earnings at the time of the survey \\
\hline \multicolumn{2}{|c|}{ During the two year period $2000-2001$} \\
\hline Employed at least 6 months & $\begin{array}{l}\text { Person has been employed for at least } 6 \text { months during the period } \\
\text { 2000-2001 (dummy variable) }\end{array}$ \\
\hline Employed at least 12 months & $\begin{array}{l}\text { Person has been employed for at least } 12 \text { months during the period } \\
\text { 2000-2001 (dummy variable) }\end{array}$ \\
\hline Months unemployed & $\begin{array}{l}\text { Number of months the person has been unemployed during the period } \\
2000-2001\end{array}$ \\
\hline Months receiving UB payments & $\begin{array}{l}\text { Number of months the person has been registered with the Public } \\
\text { Employment Services and receiving unemployment benefits payment } \\
\text { during the period 2000-2001 }\end{array}$ \\
\hline Average monthly earnings & Average monthly earnings during the two-year period 2000-2001 \\
\hline
\end{tabular}

Note: Earnings are deflated by gross domestic product (base=1998). Earnings are coded as zero if person reported not working at the time of the survey. 
Table 9

Outcomes for ALMP Participants

(Percentages except where noted)

\begin{tabular}{|c|c|c|c|c|}
\hline & $\begin{array}{c}\text { Training and } \\
\text { Retraining }\end{array}$ & $\begin{array}{c}\text { Self-Employment } \\
\text { Assistance }\end{array}$ & Public Employment & $\begin{array}{c}\text { Employment } \\
\text { and } \\
\text { Relocation }\end{array}$ \\
\hline \multicolumn{5}{|l|}{ OUTCOMES } \\
\hline \multicolumn{5}{|l|}{ Current experience } \\
\hline Employed & 57.81 & 50.86 & 31.74 & 51.28 \\
\hline Average monthly earnings (in thousand lei) & 311.76 & 303.28 & 160.96 & 309.64 \\
\hline \multicolumn{5}{|l|}{ During the two year period $2000-2001$} \\
\hline Employed for at least 6 months & 75.00 & 78.86 & 48.17 & 78.87 \\
\hline Employed for at least 12 months & 65.62 & 59.71 & 33.56 & 63.39 \\
\hline Average monthly earnings (in thousand lei) & 449.42 & 398.60 & 256.12 & 394.34 \\
\hline Months unemployed & 9.52 & 10.36 & 16.22 & 9.45 \\
\hline Months receiving UB payments & 0.06 & 1.44 & 1.78 & 0.79 \\
\hline Sample size & 72 & 362 & 445 & 747 \\
\hline
\end{tabular}

Monthly earnings have been deflated using 1998 deflator. 


\section{Table 10}

Average Treatment Effects of Programmes on the Employment Experience of their Participants, by ALMPs (Percentage points except where noted)

\begin{tabular}{|c|c|c|c|c|}
\hline & $\begin{array}{l}\text { Training and } \\
\text { Retraining }\end{array}$ & $\begin{array}{l}\text { Self-Employment } \\
\text { Assistance }\end{array}$ & Public Employment & $\begin{array}{c}\text { Employment and } \\
\text { Relocation }\end{array}$ \\
\hline \multicolumn{5}{|l|}{$\begin{array}{r}\text { OUTCOMES } \\
\end{array}$} \\
\hline \multicolumn{5}{|l|}{ Current experience } \\
\hline Employed & $\begin{array}{c}12.47 \\
(-7 . .00 ; 29.54)\end{array}$ & $\begin{array}{c}6.14 \\
(-0.44 \quad 12.29)\end{array}$ & $\begin{array}{c}0.61 \\
(-6.07 ; 6.29)\end{array}$ & $\begin{array}{c}8.45 \\
(3.19 ; 13.90)\end{array}$ \\
\hline Average monthly earnings (in thousand lei) & $\begin{array}{c}65.67 \\
(-76.45 ; 177.64)\end{array}$ & $\begin{array}{c}37.58 \\
(-13.25 ; 80.12)\end{array}$ & $\begin{array}{c}3.10 \\
(-33.87 ; 33.44)\end{array}$ & $\begin{array}{c}56.86 \\
(10.49 ; 109.51)\end{array}$ \\
\hline \multicolumn{5}{|l|}{ During the two year period 2000-2001 } \\
\hline Employed for at least 6 months & $\begin{array}{c}2.53 \\
(-10.55 ; 27.28)\end{array}$ & $\begin{array}{c}8.38 \\
(2.29 ; 14.13)\end{array}$ & $\begin{array}{c}-7.36 \\
(-14.98 ;-0.75)\end{array}$ & $\begin{array}{c}6.22 \\
(2.35 ; 13.52)\end{array}$ \\
\hline Employed for at least 12 months & $\begin{array}{c}8.06 \\
(-10.76 ; 26.91)\end{array}$ & $\begin{array}{c}7.97 \\
(-0.20 ; 14.40)\end{array}$ & $\begin{array}{c}-8.45 \\
(-15.41-1.40)\end{array}$ & $\begin{array}{c}7.65 \\
(2.11 ; 13.73)\end{array}$ \\
\hline Average monthly earnings (in thousand lei) & $\begin{array}{c}164.81 \\
(63.09 ; 362.20)\end{array}$ & $\begin{array}{c}43.08 \\
(-9.48 ; 87.58)\end{array}$ & $\begin{array}{c}-6.65 \\
(-47.29 ; 30.33)\end{array}$ & $\begin{array}{c}87.32 \\
(56.99 ; 130.21)\end{array}$ \\
\hline Months unemployed & $\begin{array}{c}-1.66 \\
(-4.91 ; 2.79)\end{array}$ & $\begin{array}{c}-1.82 \\
(-3.00-0.54)\end{array}$ & $\begin{array}{c}1.95 \\
(0.66 ; 3.21)\end{array}$ & $\begin{array}{c}-1.90 \\
(-3.15 ;-0.92)\end{array}$ \\
\hline Months receiving UB payments & $\begin{array}{c}-1.01 \\
(-2.24 ;-0.53)\end{array}$ & $\begin{array}{c}-0.75 \\
(-1.50 ;-0.05)\end{array}$ & $\begin{array}{c}0.21 \\
(-0.60 ; 0.93) \\
\end{array}$ & $\begin{array}{c}-0.74 \\
(-1.18 ;-0.29) \\
\end{array}$ \\
\hline Sample size & 768 & 1,311 & 1,445 & 1,748 \\
\hline
\end{tabular}


Table 11

Impacts of Training and Retraining Services

(Percentage points except where noted)

\begin{tabular}{|c|c|c|c|c|}
\hline & \multicolumn{2}{|c|}{ PARTICIPANTS VS. NON-PARTICIPANTS } & \multicolumn{2}{|c|}{$\begin{array}{c}\text { PARTICIPANTS VS. MATCHED NON- } \\
\text { PARTICIPANTS }\end{array}$} \\
\hline & Difference of Means & $\begin{array}{c}\text { Regression Adjusted } \\
\text { (using all observable } \\
\text { variables) }\end{array}$ & $\begin{array}{l}\text { Difference of Means } \\
\text { (using all observable } \\
\text { variables, with the } \\
\text { exception of pre- } \\
\text { employment history, to } \\
\text { match participants to } \\
\text { non-participants) }\end{array}$ & $\begin{array}{l}\text { Difference of Means } \\
\text { (using all observable } \\
\text { variables to match } \\
\text { participants to non- } \\
\text { participants) }\end{array}$ \\
\hline \multicolumn{5}{|l|}{ OUTCOMES } \\
\hline \multicolumn{5}{|l|}{ Current experience } \\
\hline Average monthly earnings (in thousand lei) & $\begin{array}{c}19.09 \\
(0.59) \\
80.47 \\
(43.26)\end{array}$ & $\begin{array}{c}18.10 \\
(7.80) \\
68.90 \\
(43.58)\end{array}$ & $\begin{array}{c}16.00 \\
(4.32 ; 28.34) \\
21.44 \\
(-225.22 ; 132.65)\end{array}$ & $\begin{array}{c}12.47 \\
(-7.00 ; 29.54) \\
65.67 \\
(-76.45 ; 177.64)\end{array}$ \\
\hline \multicolumn{5}{|l|}{ During the two year period 2000-2001 } \\
\hline Employed for at least 6 months & $\begin{array}{c}8.17 \\
(5.09)\end{array}$ & $\begin{array}{l}10.04 \\
(5.61)\end{array}$ & $\begin{array}{c}9.09 \\
(-3.52 ; 2.17)\end{array}$ & $\begin{array}{c}2.53 \\
(-10.55 ; 27.28)\end{array}$ \\
\hline Employed for at least 12 months & $\begin{array}{l}16.09 \\
(5.60)\end{array}$ & $\begin{array}{l}20.49 \\
(6.72)\end{array}$ & $\begin{array}{c}17.32 \\
(4.46 ; 3.14)\end{array}$ & $\begin{array}{c}8.06 \\
(-10.76 ; 26.91)\end{array}$ \\
\hline Average monthly earnings (in thousand lei) & $\begin{array}{l}129.29 \\
(50.08)\end{array}$ & $\begin{array}{l}144.70 \\
(46.01)\end{array}$ & $\begin{array}{c}113.64 \\
(1.08 ; 212.78)\end{array}$ & $\begin{array}{c}164.81 \\
(63.09 ; 362.20)\end{array}$ \\
\hline Months unemployed & $\begin{array}{l}-3.18 \\
(1.19)\end{array}$ & $\begin{array}{l}-3.99 \\
(1.28)\end{array}$ & $\begin{array}{c}-3.80 \\
(-6.74 ;-1.09)\end{array}$ & $\begin{array}{c}-1.66 \\
(-4.91 ; 2.79)\end{array}$ \\
\hline Months receiving UB payments & $\begin{array}{l}-1.74 \\
(0.14)\end{array}$ & $\begin{array}{l}-1.66 \\
(0.31) \\
\end{array}$ & $\begin{array}{c}-1.93 \\
(-2.77 ;-1.28) \\
\end{array}$ & $\begin{array}{c}-1.01 \\
(-2.24 ;-0.53)\end{array}$ \\
\hline Sample size & 1,573 & 1,573 & 741 & 768 \\
\hline Sample size of the treatment group & 72 & 72 & 70 & 61 \\
\hline Sample size of the comparison group & 1,501 & 1,501 & 671 & 553 \\
\hline
\end{tabular}


Table 12

Impacts of Self-Employment Assistance Program

(Percentage points except where noted)

\begin{tabular}{|c|c|c|c|c|}
\hline & \multicolumn{2}{|c|}{ PARTICIPANTS VS. NON-PARTICIPANTS } & \multicolumn{2}{|c|}{$\begin{array}{l}\text { PARTICIPANTS VS. MATCHED NON- } \\
\text { PARTICIPANTS }\end{array}$} \\
\hline & Difference of Means & $\begin{array}{l}\text { Regression Adjusted } \\
\text { (using all observable } \\
\text { variables) }\end{array}$ & $\begin{array}{l}\text { Difference of Means } \\
\text { (using all observable } \\
\text { variables, with the } \\
\text { exception of pre- } \\
\text { employment history, to } \\
\text { match participants to } \\
\text { non-participants) }\end{array}$ & $\begin{array}{l}\text { Difference of Means } \\
\text { (using all observable } \\
\text { variables to match } \\
\text { participants to non- } \\
\text { participants) }\end{array}$ \\
\hline \multicolumn{5}{|l|}{$\begin{array}{r}\text { OUTCOMES } \\
\end{array}$} \\
\hline \multicolumn{5}{|l|}{ Current experience } \\
\hline Average monthly earnings (in thousand lei) & $\begin{array}{l}12.42 \\
(2.90) \\
80.04 \\
(22.45)\end{array}$ & $\begin{array}{c}7.68 \\
(3.7) \\
40.50 \\
(20.87)\end{array}$ & $\begin{array}{c}7.52 \\
(0.01 ; 13.22) \\
40.67 \\
(-6.56 ; 84.21)\end{array}$ & $\begin{array}{c}6.14 \\
(-0.44 \quad 12.29) \\
37.58 \\
(-13.25 ; 80.12)\end{array}$ \\
\hline \multicolumn{5}{|l|}{ During the two year period 2000-2001 } \\
\hline Employed for at least 6 months & $\begin{array}{l}11.06 \\
(2.43)\end{array}$ & $\begin{array}{l}9.92 \\
(2.83)\end{array}$ & $\begin{array}{c}10.27 \\
(3.91 ; 15.50)\end{array}$ & $\begin{array}{c}8.38 \\
(2.29 ; 14.13)\end{array}$ \\
\hline Employed for at least 12 months & $\begin{array}{c}8.53 \\
(2.84)\end{array}$ & $\begin{array}{l}8.77 \\
(3.6)\end{array}$ & $\begin{array}{c}9.11 \\
(2.14 ; 15.91)\end{array}$ & $\begin{array}{c}7.97 \\
(-0.20 ; 14.40)\end{array}$ \\
\hline Average monthly earnings (in thousand lei) & $\begin{array}{c}80.43 \\
(21.91)\end{array}$ & $\begin{array}{c}21.09 \\
(21.29)\end{array}$ & $\begin{array}{c}40.29 \\
(-10.36 ; 82.64)\end{array}$ & $\begin{array}{c}43.08 \\
(-9.48 ; 87.58)\end{array}$ \\
\hline Months unemployed & $\begin{array}{l}-0.99 \\
(0.28)\end{array}$ & $\begin{array}{l}-1.74 \\
(0.57)\end{array}$ & $\begin{array}{c}-2.30 \\
(-3.52 ;-1.13)\end{array}$ & $(-3.00-0.54)$ \\
\hline Months receiving UB payments & $\begin{array}{l}-0.17 \\
(0.15)\end{array}$ & $\begin{array}{l}-0.75 \\
(0.33)\end{array}$ & $\begin{array}{c}-1.11 \\
(-1.89 ;-.41) \\
\end{array}$ & $\begin{array}{c}-0.75 \\
(-1.50 ;-0.05) \\
\end{array}$ \\
\hline Sample size & 1,863 & 1,863 & 1,318 & 1,311 \\
\hline Sample size of the treatment group & 362 & 362 & 358 & 350 \\
\hline Sample size of the comparison group & 1,501 & 1,501 & 960 & 961 \\
\hline
\end{tabular}


Table 13

Impacts of Public Employment Services

(Percentage points except where noted)

\begin{tabular}{|c|c|c|c|c|}
\hline & \multicolumn{2}{|c|}{ PARTICIPANTS VS. NON-PARTICIPANTS } & \multicolumn{2}{|c|}{$\begin{array}{l}\text { PARTICIPANTS VS. MATCHED NON- } \\
\text { PARTICIPANTS }\end{array}$} \\
\hline & Difference of Means & $\begin{array}{l}\text { Regression Adjusted } \\
\text { (using all observable } \\
\text { variables) }\end{array}$ & $\begin{array}{l}\text { Difference of Means } \\
\text { (using all observable } \\
\text { variables, with the } \\
\text { exception of pre- } \\
\text { employment history, to } \\
\text { match participants to } \\
\text { non-participants) }\end{array}$ & $\begin{array}{l}\text { Difference of Means } \\
\text { (using all observable } \\
\text { variables to match } \\
\text { participants to non- } \\
\text { participants) }\end{array}$ \\
\hline \multicolumn{5}{|l|}{ OUTCOMES } \\
\hline \multicolumn{5}{|l|}{ Current experience } \\
\hline Average monthly earnings (in thousand lei) & $\begin{array}{l}-7.17 \\
(2.54) \\
-70.14 \\
(15.77)\end{array}$ & $\begin{array}{c}-3.23 \\
(3.4) \\
-17.82 \\
(16.07)\end{array}$ & $\begin{array}{c}-4.35 \\
(-10.20 ; 1.15) \\
-34.66 \\
(-70.70 ;-4.48)\end{array}$ & $\begin{array}{c}0.61 \\
(-6.07 ; 6.29) \\
3.10 \\
(-33.87 ; 33.44)\end{array}$ \\
\hline \multicolumn{5}{|l|}{ During the two year period 2000-2001 } \\
\hline Employed for at least 6 months & $\begin{array}{l}-19.57 \\
(2.63)\end{array}$ & $\begin{array}{r}-11.61 \\
(3.42)\end{array}$ & $\begin{array}{c}-13.12 \\
(-19.76 ;-7.68)\end{array}$ & $\begin{array}{c}-7.36 \\
(-14.98 ;-0.75)\end{array}$ \\
\hline Employed for at least 12 months & $\begin{array}{l}-18.11 \\
(2.55)\end{array}$ & $\begin{array}{l}-13.00 \\
(3.44)\end{array}$ & $\begin{array}{c}-13.06 \\
(-19.38 ;-7.47)\end{array}$ & $\begin{array}{c}-8.45 \\
(-15.41-1.40)\end{array}$ \\
\hline Average monthly earnings (in thousand lei) & $\begin{array}{l}-63.03 \\
(16.99)\end{array}$ & $\begin{array}{l}-11.53 \\
(17.36)\end{array}$ & $\begin{array}{c}-45.58 \\
(-80.38 ;-9.37)\end{array}$ & $\begin{array}{c}-6.65 \\
(-47.29 ; 30.33)\end{array}$ \\
\hline Months unemployed & $\begin{array}{c}1.33 \\
(0.17)\end{array}$ & $\begin{array}{c}2.41 \\
(0.56)\end{array}$ & $\begin{array}{c}2.99 \\
(1.90 ; 4.31)\end{array}$ & $\begin{array}{c}1.95 \\
(0.66 ; 3.21)\end{array}$ \\
\hline Months receiving UB payments & $\begin{array}{l}-0.1 \\
(0.09)\end{array}$ & $\begin{array}{c}0.44 \\
(0.32)\end{array}$ & $\begin{array}{c}0.34 \\
(-0.30 ; 0.99)\end{array}$ & $\begin{array}{c}0.21 \\
(-0.60 ; 0.93)\end{array}$ \\
\hline Sample size & 1,947 & 1,947 & 1,714 & 1,445 \\
\hline Sample size of the treatment group & 445 & 445 & 445 & 439 \\
\hline Sample size of the comparison group & 1,501 & 1,501 & 1,269 & 1,006 \\
\hline
\end{tabular}

Monthly earnings have been deflated using 1998 deflator. 
Table 14

Impacts of Employment and Relocation Services

(Percentage points except where noted)

\begin{tabular}{|c|c|c|c|c|}
\hline & \multicolumn{2}{|c|}{ PARTICIPANTS VS. NON-PARTICIPANTS } & \multicolumn{2}{|c|}{$\begin{array}{l}\text { PARTICIPANTS VS. MATCHED NON- } \\
\text { PARTICIPANTS }\end{array}$} \\
\hline & Difference of Means & $\begin{array}{c}\text { Regression Adjusted } \\
\text { (using all observable } \\
\text { variables) }\end{array}$ & $\begin{array}{l}\text { Difference of Means } \\
\text { (using all observable } \\
\text { variables, with the } \\
\text { exception of pre- } \\
\text { employment history, to } \\
\text { match participants to } \\
\text { non-participants) }\end{array}$ & $\begin{array}{l}\text { Difference of Means } \\
\text { (using all observable } \\
\text { variables to match } \\
\text { participants to non- } \\
\text { participants) }\end{array}$ \\
\hline \multicolumn{5}{|l|}{$\begin{array}{r}\text { OUTCOMES } \\
\end{array}$} \\
\hline \multicolumn{5}{|l|}{ Current experience } \\
\hline Average monthly earnings (in thousand lei) & $\begin{array}{c}12.17 \\
(2.22) \\
77.44 \\
(20.38)\end{array}$ & $\begin{array}{c}12.16 \\
(2.95) \\
78.43 \\
(21.46)\end{array}$ & $\begin{array}{c}9.81 \\
(5.25 ; 14.25) \\
56.32 \\
(11.92 ; 97.90)\end{array}$ & $\begin{array}{c}8.45 \\
(3.19 ; 13.90) \\
56.86 \\
(10.49 ; 109.51)\end{array}$ \\
\hline \multicolumn{5}{|l|}{ During the two year period 2000-2001 } \\
\hline Employed for at least 6 months & $\begin{array}{l}10.63 \\
(1.90)\end{array}$ & $\begin{array}{c}9.83 \\
(2.22)\end{array}$ & $\begin{array}{c}9.07 \\
(4.66 ; 13.18)\end{array}$ & $\begin{array}{c}6.22 \\
(2.35 ; 13.52)\end{array}$ \\
\hline Employed for at least 12 months & $\begin{array}{l}11.49 \\
(2.17)\end{array}$ & $\begin{array}{l}11.93 \\
(2.72)\end{array}$ & $\begin{array}{c}11.24 \\
(6.29 ; 15.43)\end{array}$ & $\begin{array}{c}7.65 \\
(2.11 ; 13.73)\end{array}$ \\
\hline Average monthly earnings (in thousand lei) & $\begin{array}{c}71.97 \\
(16.24)\end{array}$ & $\begin{array}{c}84.19 \\
(15.83)\end{array}$ & $\begin{array}{c}62.37 \\
(25.48 ; 92.84)\end{array}$ & $\begin{array}{c}87.32 \\
(56.99 ; 130.21)\end{array}$ \\
\hline Months unemployed & $\begin{array}{l}-0.68 \\
(0.11)\end{array}$ & $\begin{array}{l}-2.40 \\
(0.45)\end{array}$ & $\begin{array}{c}-2.57 \\
(-3.39 ;-1.71)\end{array}$ & $\begin{array}{c}-1.90 \\
(-3.15 ;-0.92)\end{array}$ \\
\hline Months receiving UB payments & $\begin{array}{l}-0.25 \\
(0.05)\end{array}$ & $\begin{array}{l}-1.17 \\
(0.21)\end{array}$ & $\begin{array}{c}-1.42 \\
(-1.87 ;-.91) \\
\end{array}$ & $\begin{array}{c}-0.74 \\
(-1.18 ;-0.29) \\
\end{array}$ \\
\hline Sample size & 2,248 & 2,248 & 1,724 & 1,748 \\
\hline Sample size of the treatment group & 747 & 747 & 746 & 743 \\
\hline Sample size of the comparison group & 1,501 & 1,501 & 978 & 1,005 \\
\hline
\end{tabular}


Table 15

Average treatment effects of Training and Retraining Services according to different socio-demographic characteristics (Percentage points except where noted)

\begin{tabular}{|c|c|c|c|c|c|c|c|c|c|c|}
\hline & Males & Females & $\begin{array}{c}<36 \text { years } \\
\text { old }\end{array}$ & $\begin{array}{c}>35 \\
\text { years old }\end{array}$ & $\begin{array}{l}\text { No high } \\
\text { school } \\
\text { diploma }\end{array}$ & $\begin{array}{c}\text { High } \\
\text { school } \\
\text { diploma or } \\
\text { more }\end{array}$ & $\begin{array}{l}\text { Unemployment } \\
<6 \text { months }\end{array}$ & $\begin{array}{l}\text { Unemployment } \\
>5 \text { months }\end{array}$ & Rural & Urban \\
\hline \multicolumn{11}{|l|}{ OUTCOMES } \\
\hline \multicolumn{11}{|l|}{ Current experience } \\
\hline Employed & 11.90 & 20.73 & 25.64 & 13.58 & 13.81 & 9.30 & 8.51 & 5.32 & n.a. & 3.07 \\
\hline $\begin{array}{l}\text { Average wage } \\
\text { (in tousand lei) }\end{array}$ & 89.10 & 76.37 & 147.63 & 58.50 & 79.73 & 119.34 & 78.16 & -52.80 & n.a. & 13.18 \\
\hline \multicolumn{11}{|c|}{ During the two year period 2000-2001 } \\
\hline $\begin{array}{l}\text { Employed for at least } \\
6 \text { months }\end{array}$ & -2.72 & 0.92 & 14.01 & -8.47 & 0.96 & -0.71 & 11.61 & 6.43 & n.a. & -6.92 \\
\hline $\begin{array}{l}\text { Employed for at least } \\
12 \text { months }\end{array}$ & 8.17 & 17.24 & 34.42 & 3.11 & 5.75 & 10.08 & 17.63 & 7.98 & n.a. & 4.73 \\
\hline $\begin{array}{l}\text { Average wage } \\
\text { (in thousand lei) }\end{array}$ & 173.83 & 116.59 & 230.69 & 103.24 & $194.67 *$ & 95.60 & 138.95 & 86.77 & n.a. & 88.23 \\
\hline $\begin{array}{l}\text { Months } \\
\text { unemployment }\end{array}$ & 0.25 & -3.67 & -6.45 & -0.29 & -3.09 & -1.79 & -3.79 & -2.85 & n.a. & -1.53 \\
\hline $\begin{array}{l}\text { Months receiving UB } \\
\text { payments }\end{array}$ & $-1.31 *$ & -0.51 & $-1.65^{*}$ & $-1.14^{*}$ & $-0.95 *$ & $-0.82^{*}$ & $-1.14^{*}$ & $0.08 *$ & n.a. & $-0.83^{*}$ \\
\hline Sample size & 192 & 105 & 62 & 265 & 273 & 49 & 190 & 72 & n.a. & 375 \\
\hline $\begin{array}{l}\text { Sample size of the } \\
\text { treatment group }\end{array}$ & 27 & 27 & 16 & 38 & 41 & 14 & 26 & 19 & n.a. & 46 \\
\hline $\begin{array}{l}\text { Sample size of the } \\
\text { comparison group }\end{array}$ & 165 & 78 & 46 & 227 & 232 & 35 & 164 & 53 & n.a. & 329 \\
\hline
\end{tabular}

Monthly earnings have been deflated using 1998 deflator.

* indicates that estimates are significant at the $5 \%$ level.

$\checkmark$ indicates that the difference of the two estimated effects is significant at the $5 \%$ level.

Note: the number of observations does not necessarily add up to the one in the full sample. 
Table 16

Average treatment effects of Self-Employment Assistance according to different socio-demographic characteristics (Percentage points except where noted)

\begin{tabular}{|c|c|c|c|c|c|c|c|c|c|c|}
\hline & Males & Females & $\begin{array}{c}<36 \text { years } \\
\text { old }\end{array}$ & $\begin{array}{c}>35 \\
\text { years old }\end{array}$ & $\begin{array}{c}\text { No high } \\
\text { school } \\
\text { diploma }\end{array}$ & $\begin{array}{c}\text { High } \\
\text { school } \\
\text { diploma or } \\
\text { more } \\
\end{array}$ & $\begin{array}{l}\text { Unemployment } \\
<6 \text { months }\end{array}$ & $\begin{array}{l}\text { Unemployment } \\
>5 \text { months }\end{array}$ & Rural & Urban \\
\hline \multicolumn{11}{|l|}{ OUTCOMES } \\
\hline \multicolumn{11}{|l|}{ Current experience } \\
\hline Employed & 1.18 & 2.83 & -2.83 & $9.01 *$ & 5.48 & 5.15 & 4.29 & 18.98 & 9.90 & 4.00 \\
\hline $\begin{array}{l}\text { Average wage } \\
\text { (in tousand lei) }\end{array}$ & 8.59 & 23.63 & -51.40 & $58.01^{*}$ & 20.34 & 41.30 & 31.46 & $204.01^{*}$ & 36.90 & 42.54 \\
\hline \multicolumn{11}{|c|}{ During the two year period 2000-2001 } \\
\hline $\begin{array}{l}\text { Employed for at least } \\
6 \text { months }\end{array}$ & 1.47 & $13.15^{*}$ & 9.35 & 8.31 & $13.45^{*}$ & 4.89 & 5.64 & 3.15 & $19.89 * \checkmark$ & $0.06 \checkmark$ \\
\hline $\begin{array}{l}\text { Employed for at least } \\
12 \text { months }\end{array}$ & 3.68 & 9.04 & 12.89 & $10.76^{*}$ & $19.35 * \checkmark$ & $1.45 \checkmark$ & 3.65 & 4.35 & $19.06 * \checkmark$ & $5.38 \checkmark$ \\
\hline $\begin{array}{l}\text { Average wage } \\
\text { (in thousand lei) }\end{array}$ & -21.72 & 46.86 & 5.11 & 43.27 & 47.95 & 14.68 & 19.68 & 123.90 & 10.28 & 34.48 \\
\hline $\begin{array}{l}\text { Months } \\
\text { unemployment }\end{array}$ & -1.03 & -1.55 & -2.50 & $-2.22 *$ & $-3.61 * \checkmark$ & $-0.57 \checkmark$ & -1.02 & -1.55 & $-3.64 * \checkmark$ & $-1.20 \checkmark$ \\
\hline $\begin{array}{l}\text { Months receiving UB } \\
\text { payments }\end{array}$ & -0.68 & -1.16 & -0.71 & -0.75 & $-1.93 * \checkmark$ & $6.06^{\checkmark}$ & -0.70 & -0.01 & $-3.61 * \checkmark$ & $0.36 \checkmark$ \\
\hline Sample size & 790 & 463 & 273 & 955 & 595 & 687 & 966 & 208 & 427 & 774 \\
\hline $\begin{array}{l}\text { Sample size of the } \\
\text { treatment group }\end{array}$ & 181 & 175 & 97 & 254 & 200 & 150 & 244 & 45 & 142 & 210 \\
\hline $\begin{array}{l}\text { Sample size of the } \\
\text { comparison group }\end{array}$ & 609 & 288 & 176 & 701 & 395 & 537 & 722 & 163 & 285 & 564 \\
\hline
\end{tabular}

Monthly earnings have been deflated using 1998 deflator.

* indicates that estimates are significant at the $5 \%$ level.

$\checkmark$ indicates that the difference of the two estimated effects is significant at the $5 \%$ level.

Note: the number of observations does not necessarily add up to the one in the full sample. 
Table 17

Average treatment effects of Public Employment according to different socio-demographic characteristics (Percentage points except where noted)

\begin{tabular}{|c|c|c|c|c|c|c|c|c|c|c|}
\hline & Males & Females & $\begin{array}{c}<36 \text { years } \\
\text { old }\end{array}$ & $\begin{array}{c}>35 \\
\text { years old }\end{array}$ & $\begin{array}{c}\text { No high } \\
\text { school } \\
\text { diploma }\end{array}$ & $\begin{array}{c}\text { High } \\
\text { school } \\
\text { diploma or } \\
\text { more }\end{array}$ & $\begin{array}{l}\text { Unemployment } \\
<6 \text { months }\end{array}$ & $\begin{array}{l}\text { Unemployment } \\
>5 \text { months }\end{array}$ & Rural & Urban \\
\hline \multicolumn{11}{|l|}{ OUTCOMES } \\
\hline \multicolumn{11}{|l|}{ Current experience } \\
\hline Employed & 0.38 & -1.57 & -3.76 & 3.39 & 2.49 & -3.02 & -1.09 & 4.53 & $10.91 * \checkmark$ & $-8.99 \checkmark$ \\
\hline $\begin{array}{l}\text { Average wage } \\
\text { (in tousand lei) }\end{array}$ & -1.42 & 1.17 & -28.42 & 27.71 & 19.78 & -31.18 & -9.88 & 28.64 & $58.30 * \checkmark$ & $-45.49 \checkmark$ \\
\hline \multicolumn{11}{|c|}{ During the two year period 2000-2001 } \\
\hline $\begin{array}{l}\text { Employed for at least } \\
6 \text { months }\end{array}$ & -6.93 & -17.93 & -1.79 & $-10.46 *$ & -6.28 & -11.08 & -11.04 & -3.56 & -4.42 & -10.55 \\
\hline $\begin{array}{l}\text { Employed for at least } \\
12 \text { months }\end{array}$ & $-8.46 *$ & -13.17 & -8.36 & $-9.58 *$ & -6.00 & $-14.69 *$ & -7.62 & -5.80 & -6.20 & $-11.72 *$ \\
\hline $\begin{array}{l}\text { Average wage } \\
\text { (in thousand lei) }\end{array}$ & -4.25 & -2.47 & -37.00 & 11.56 & 4.59 & -51.15 & 20.90 & 1.21 & 1.44 & $-15.28 *$ \\
\hline $\begin{array}{l}\text { Months } \\
\text { unemployment }\end{array}$ & $1.94 *$ & 3.31 & 1.71 & $2.26 *$ & 1.42 & $3.46 *$ & 2.02 & 1.34 & $0.95 \checkmark$ & $3.04 * \checkmark$ \\
\hline $\begin{array}{l}\text { Months receiving UB } \\
\text { payments }\end{array}$ & -0.06 & 2.42 & -0.19 & 0.41 & -0.01 & -0.26 & 0.00 & 0.35 & $0.62 \checkmark$ & $-0.50 \checkmark$ \\
\hline Sample size & 1,105 & 127 & 340 & 992 & 901 & 389 & 830 & 331 & 618 & 759 \\
\hline $\begin{array}{l}\text { Sample size of the } \\
\text { treatment group }\end{array}$ & 392 & 37 & 133 & 296 & 344 & 96 & 247 & 90 & 236 & 201 \\
\hline $\begin{array}{l}\text { Sample size of the } \\
\text { comparison group }\end{array}$ & 713 & 90 & 207 & 696 & 557 & 293 & 583 & 241 & 382 & 558 \\
\hline
\end{tabular}

Monthly earnings have been deflated using 1998 deflator.

* indicates that estimates are significant at the $5 \%$ level.

$\checkmark$ indicates that the difference of the two estimated effects is significant at the $5 \%$ level.

Note: the number of observations does not necessarily add up to the one in the full sample. 
Table 18

Average treatment effects of Employment and Relocation Services according to different socio-demographic characteristics (Percentage points except where noted)

\begin{tabular}{|c|c|c|c|c|c|c|c|c|c|c|}
\hline & Males & Females & $\begin{array}{c}<36 \text { years } \\
\text { old }\end{array}$ & $\begin{array}{c}>35 \\
\text { years old }\end{array}$ & $\begin{array}{c}\text { No high } \\
\text { school } \\
\text { diploma }\end{array}$ & $\begin{array}{c}\text { High } \\
\text { school } \\
\text { diploma or } \\
\text { more } \\
\end{array}$ & $\begin{array}{c}\text { Unemployment } \\
<6 \text { months }\end{array}$ & $\begin{array}{l}\text { Unemployment } \\
>5 \text { months }\end{array}$ & Rural & Urban \\
\hline \multicolumn{11}{|l|}{ OUTCOMES } \\
\hline \multicolumn{11}{|l|}{ Current experience } \\
\hline Employed & $8.95^{*}$ & $8.24 *$ & $16.89 *$ & $6.73 *$ & 5.86 & $11.28 *$ & $12.25 * \checkmark$ & $-3.83 \sqrt{ }$ & $17.93^{*}$ & $6.13^{*}$ \\
\hline $\begin{array}{l}\text { Average wage } \\
\text { (in tousand lei) }\end{array}$ & $85.24 *$ & 44.19 & 65.73 & $60.67 *$ & 73.48 & $55.11^{*}$ & $102.01 * \checkmark$ & $-70.20 * \checkmark$ & $91.54^{*}$ & 47.19 \\
\hline \multicolumn{11}{|c|}{ During the two year period 2000-2001 } \\
\hline $\begin{array}{l}\text { Employed for at least } \\
6 \text { months }\end{array}$ & $6.65^{*}$ & 6.83 & $17.78 * \checkmark$ & $3.96 \checkmark$ & 3.87 & 6.47 & $7.55 * \checkmark$ & $-5.02 \checkmark$ & 7.73 & $3.68^{*}$ \\
\hline $\begin{array}{l}\text { Employed for at least } \\
12 \text { months }\end{array}$ & $8.18^{*}$ & $9.64^{*}$ & $26.20 * \checkmark$ & $4.12^{\checkmark}$ & 5.39 & 9.13* & 7.33* & -1.15 & $17.25^{*}$ & 5.09 \\
\hline $\begin{array}{l}\text { Average wage } \\
\text { (in thousand lei) }\end{array}$ & $109.04^{*}$ & $59.27 *$ & $116.62 *$ & $82.81^{*}$ & 60.08 & $97.01^{*}$ & $91.47^{*}$ & 18.83 & $144.24 * \checkmark$ & $50.42 * \checkmark$ \\
\hline $\begin{array}{l}\text { Months } \\
\text { unemployment }\end{array}$ & $-2.42 *$ & $-1.79 *$ & $-4.62 * \checkmark$ & $-1.21 \checkmark$ & -1.40 & $-1.96 *$ & $-2.04 *$ & -0.20 & $-4.87 * \checkmark$ & $-0.96 \checkmark$ \\
\hline $\begin{array}{l}\text { Months receiving UB } \\
\text { payments }\end{array}$ & $-0.33 \checkmark$ & $-1.22 * \checkmark$ & -0.66 & $-0.76^{*}$ & $-0.83^{*}$ & -0.76 & $-1.00 *$ & -0.21 & $-1.57^{*}$ & $-0.50 *$ \\
\hline Sample size & 901 & 804 & 362 & 1,365 & 977 & 725 & 1,282 & 324 & 454 & 1,177 \\
\hline $\begin{array}{l}\text { Sample size of the } \\
\text { treatment group }\end{array}$ & 338 & 400 & 159 & 577 & 438 & 296 & 482 & 213 & 189 & 531 \\
\hline $\begin{array}{l}\text { Sample size of the } \\
\text { comparison group }\end{array}$ & 563 & 404 & 203 & 788 & 539 & 429 & 1,282 & 111 & 265 & 646 \\
\hline
\end{tabular}

Monthly earnings have been deflated using 1998 deflator.

* indicates that estimates are significant at the $5 \%$ level.

$\checkmark$ indicates that the difference of the two estimated effects is significant at the $5 \%$ level.

Note: the number of observations does not necessarily add up to the one in the full sample. 